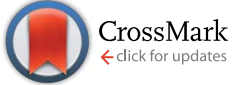

Cite this: RSC Adv., 2016, 6, 13193

Received 6th December 2015 Accepted 25th January 2016

DOI: $10.1039 / \mathrm{c} 5 \mathrm{ra} 26002 \mathrm{~g}$

www.rsc.org/advances

\section{A comparative antimicrobial and toxicological study of gold(III) and silver(I) complexes with aromatic nitrogen-containing heterocycles: synergistic activity and improved selectivity index of $\mathrm{Au}(\mathrm{III}) / \mathrm{Ag}(\mathrm{I})$ complexes mixture $\dagger$}

\author{
Nada D. Savić, ${ }^{a}$ Dusan R. Milivojevic, ${ }^{b}$ Biljana Đ. Glišić, ${ }^{* a}$ Tatjana Ilic-Tomic, ${ }^{b}$ \\ Jovana Veselinovic, ${ }^{c}$ Aleksandar Pavic, ${ }^{\text {b }}$ Branka Vasiljevic, ${ }^{\text {b }}$ \\ Jasmina Nikodinovic-Runic ${ }^{* b}$ and Miloš I. Djuran ${ }^{a}$
}

Five aromatic nitrogen-containing heterocycles, pyridazine (pydz, 1), pyrimidine (pm, 2), pyrazine (pz, 3), quinoxaline (qx, 4) and phenazine (phz, 5) have been used for the synthesis of gold(II) and silver(I) complexes. In contrast to the mononuclear Au1-5 complexes all having square-planar geometry, the corresponding Ag1-5 complexes have been found to be polynuclear and of different geometries. Complexes Au1-5 and Ag1-5, along with $\left.\mathrm{K}_{\mathrm{AuCl}}\right], \mathrm{AgNO}_{3}$ and $\mathrm{N}$-heterocyclic ligands used for their synthesis, were evaluated by in vitro antimicrobial studies against a panel of microbial strains that lead to many skin and soft tissue, respiratory, wound and nosocomial infections. All tested complexes exhibited excellent to good antibacterial activity with minimal inhibitory (MIC) values in the range of 2.5 to $100 \mu \mathrm{g}$ $\mathrm{mL}^{-1}$ against the investigated strains. The complexes were particularly efficient against pathogenic Pseudomonas aeruginosa ( $\mathrm{MIC}=2.5-30 \mu \mathrm{g} \mathrm{mL}^{-1}$ ) and had a marked ability to disrupt clinically relevant biofilms of strains with high inherent resistance to antibiotics. Moreover, the Au1-4 and Ag1-5 complexes exhibited pronounced ability to competitively intercalate double stranded genomic DNA of $P$. aeruginosa, which was demonstrated by gel electrophoresis techniques and supported by molecular docking into the DNA major groove. Antiproliferative effect on the normal human lung fibroblast cell line MRC5 has also been evaluated in order to determine therapeutic potential of Au1-5 and Ag1-5 complexes. Since the investigated gold(III) complexes showed much lower negative effects on the viability of the MRC5 cell line than their silver(I) analogues and slightly lower antimicrobial activity against the investigated strains, the combination approach to improve their pharmacological profiles was applied. Synergistic antimicrobial effect and the selectivity index of 10 were achieved for the selected gold(III)/silver(I) complexes mixtures, as well as higher $P$. aeruginosa PAO1 biofilm disruption activity, and improved toxicity profile towards zebrafish embryos, in comparison to the single complexes. To the best of our knowledge, this is the first report on synergistic activity of gold(III)/silver(I) complexes mixtures and it could have an impact on development of new combination therapy methods for the treatment of multi-resistant bacterial infections.

\section{Introduction}

Metal-based drugs have a wide range of medicinal applications, both as diagnostic and therapeutic agents, and are now

\footnotetext{
${ }^{a}$ Department of Chemistry, Faculty of Science, University of Kragujevac, R. Domanovića 12, PO Box 60, 34000 Kragujevac, Serbia.E-mail: bglisic@kg.ac.rs

${ }^{b}$ Institute of Molecular Genetics and Genetic Engineering, University of Belgrade, Vojvode Stepe 444a, 11000 Belgrade, Serbia. E-mail:jasmina.nikodinovic@gmail.com ${ }^{c}$ Faculty of Medicine, Department of Chemistry, University of Niš, $18000 \mathrm{Niš,} \mathrm{Serbia}$ $\dagger$ Electronic supplementary information (ESI) available: Fig. S1-S4 and Tables S1-S3. See DOI: $10.1039 / \mathrm{c} 5 \mathrm{ra} 26002 \mathrm{~g}$
}

routinely administered to patients. ${ }^{\mathbf{1 , 2}}$ Generally, compounds containing platinum (anticancer), silver (antimicrobial), iron (antimalarial), bismuth (antiulcer), vanadium (antidiabetic) and gold (antiarthritic) are examples of metal-based drugs which have been used for the treatment of the wide range of diseases. ${ }^{3}$ Although the mechanism of biological action of metal compounds for therapy and diagnosis has been extensively investigated, in several cases is still not fully elucidated. The activity of metal-based drugs usually relies on their redox changes and/or ligand exchange reactions in vivo to generate the active species., ${ }^{2,4}$ Metal complexes offer quite diverse chemistry in comparison to small organic bioactive molecules, due to the 
fact that their properties can be modulated by the choice of the metal oxidation state. Furthermore, the choice of the ligands used for the synthesis of metal complexes allows tuning of their lipophilicity, solubility and reactivity, which results in better therapeutic activity against toxicity. The efforts to apply known treatments or biological properties to new diseases are also ongoing. ${ }^{5}$ In the metal-based therapeutic area, good examples are development of antitumor agents from organotin complexes that have been used as fungicides and antifouling agents, or utilization of auranofin, a clinically established antiarthritic metallodrug as antimalarial, as well as evaluation of other gold(I) and gold(III) complexes as potential antimicrobial agents. $^{2,6,7}$ Another option to further develop and/or improve metal-based drugs would be to examine their potential in a combination therapy, as dual therapeutics either by mixed metal $^{8,9}$ or mixed ligand ${ }^{\mathbf{1 0}}$ approaches, or to fully exploit various biological activities within the same metal complex. At the same time, growing evidence indicates that dual or combination approaches or the development of safe and effective antimicrobials are urgently needed, especially in the case of infections associated with critically ill patients.

Among other metals, gold and silver have attracted numerous research efforts in terms of preparation of novel coordination and organometallic compounds, which have been evaluated as potential therapeutic agents. ${ }^{\mathbf{1 1}}$ Gold(I) complexes have been utilized for the treatment of rheumatoid arthritis and a variety of rheumatic diseases from the middle of $20^{\text {th }}$ century, while a large number of gold(I) and gold(III) complexes have been evaluated for their potential use in the treatment of cancer, bronchial asthma, as anti-HIV and antimicrobial agents. ${ }^{6,12}$ Silver and its various preparations have been applied for the treatment of burns and wounds, venereal diseases, abscesses, newborn conjunctivitis, in the last couple hundred years, due to the antibacterial action of silver(I) ions. ${ }^{13}$ Following the discovery of penicillin, the use of silver to treat bacteria declined, however numerous applications of silver as an antibacterial coating on surfaces of various medical and consumer products have been developed and are currently used against a range of pathogens such as Staphylococcus aureus, Pseudomonas aeruginosa and Escherichia coli. ${ }^{\mathbf{1 4 , 1 5}}$ The antibacterial mechanism of action of $\operatorname{silver(I)~ion~has~not~been~fully~eluci-~}$ dated, and more recently reports on the bacterial resistance to known silver-based medicines are more frequent. ${ }^{16}$ On the other hand, the development of novel silver(I) complexes, in which silver(I) ion is chelated by the ligands specifically tailored to enhance solubility and pharmacokinetics is ongoing. ${ }^{1}$ Such complexes may have a role in targeting pathogens associated with chronic lung infections such as cystic fibrosis or cancer. ${ }^{1}$

An important class of ligands for the synthesis of biologically active gold(III) and silver(I) complexes comprises of aromatic nitrogen-containing heterocycles (N-heterocycles). ${ }^{\mathbf{1 7 - 2 0}}$ These compounds are of great importance in the coordination, bioinorganic and supramolecular chemistry and are often found in many natural products and biologically important molecules. ${ }^{21-23}$ In the present study, five $\mathrm{N}$-heterocycles, pyridazine (pydz, 1), pyrimidine (pm, 2), pyrazine (pz, 3), quinoxaline (qx, 4) and phenazine (phz, 5), were used as ligands for the synthesis of gold(III) and silver(I) complexes. Although the synthesis of these complexes has been reported previously, ${ }^{24-30}$ their antimicrobial and toxicological effects have not been investigated. Considering this, in the present study, the in vitro antimicrobial properties of the gold(III) and silver(I) complexes with the abovementioned $\mathrm{N}$-heterocycles were evaluated, as well as their ability to combat difficult to treat bacterial biofilms. The results obtained from the antimicrobial evaluation of gold(III) and silver(I) complexes were compared to their cytotoxic and embryotoxic profiles. The ability of the investigated complexes to interact with bacterial genomic DNA (gDNA) has been evaluated through in vitro and in silico approaches. Synergistic antimicrobial and improved toxicity profile was determined for the mixtures of the selected silver(I) and gold(III) complexes.

\section{Results and discussion}

Synthesis and structural features of the gold(III) and silver(I) complexes with nitrogen-containing heterocycles

In this study, five $\mathrm{N}$-heterocycles, pyridazine (pydz, 1), pyrimidine (pm, 2), pyrazine (pz, 3), quinoxaline ( $\mathrm{qx}, 4)$ and phenazine (phz, 5), were used as ligands for the synthesis of gold(III) and silver(I) complexes (Scheme 1).

Gold(III) complexes. Mononuclear gold(III) complexes of the general formulae $\left[\mathrm{AuCl}_{3}(\mathrm{~N}\right.$-heterocycle $\left.)\right]$, Au1-5, were prepared from equimolar amounts of $\mathrm{K}\left[\mathrm{AuCl}_{4}\right]$ and the corresponding $\mathrm{N}$ heterocycle according to a procedure reported recently. ${ }^{\mathbf{2 4 2 5}}$ The structures of these complexes were also determined previously by using NMR $\left({ }^{1} \mathrm{H}\right.$ and $\left.{ }^{13} \mathrm{C} \mathrm{NMR}\right)$ and single-crystal X-ray diffraction analysis. ${ }^{24,25}$ However, in the present study, the stoichiometries of the investigated Au1-5 complexes were confirmed by elemental microanalysis, and the structures emerge from NMR $\left({ }^{1} \mathrm{H}\right.$ and ${ }^{13} \mathrm{C}$ ), IR and UV-vis spectroscopy (see Experimental section). We found that spectroscopic data for Au1-5 were in accordance with those reported previously for the mononuclear gold(III) complexes with pydz, pm, pz, qx and phz ligands, all containing one $\mathrm{Au}-\mathrm{N}$ (heterocycle) and three $\mathrm{Au}-\mathrm{Cl}$ bonds in a square planar plane (Scheme 1). ${ }^{\mathbf{2 4 , 2 5}}$

Silver(I) complexes. The silver(I) complexes Ag1-5 were prepared in a high yield $(>80 \%)$ by reacting $\mathrm{AgNO}_{3}$ with an equimolar amount of the corresponding $\mathrm{N}$-heterocyclic ligand in ethanol by modification of the procedure reported in the literature. ${ }^{26-30}$ The crystal structures of silver(I) complexes with pydz, pm, pz, qx and phz were determined by single-crystal X-ray diffraction analysis. ${ }^{26-30}$ In this study, we used NMR $\left({ }^{1} \mathrm{H}\right.$ and ${ }^{13} \mathrm{C}$ ), UV-vis and IR spectroscopic techniques for structural characterization of Ag1-5 complexes (see Experimental section). From the spectroscopic data, it was concluded that structures of the investigated silver(I) complexes are in accordance with those determined by X-ray analysis. ${ }^{26-30}$ Thus, in contrast to the mononuclear N-heterocycle-gold(III) complexes Au1-5, all having square planar coordination environment, the corresponding silver(I) complexes Ag1-5 are polynuclear and have different coordination geometries. A structural representation of Ag1-5 complexes is given in Scheme 1. As can be seen, in Ag1 complex, Ag(I) ions are symmetrically bridged by pydz ligands, while the remaining three coordination sites are occupied by 


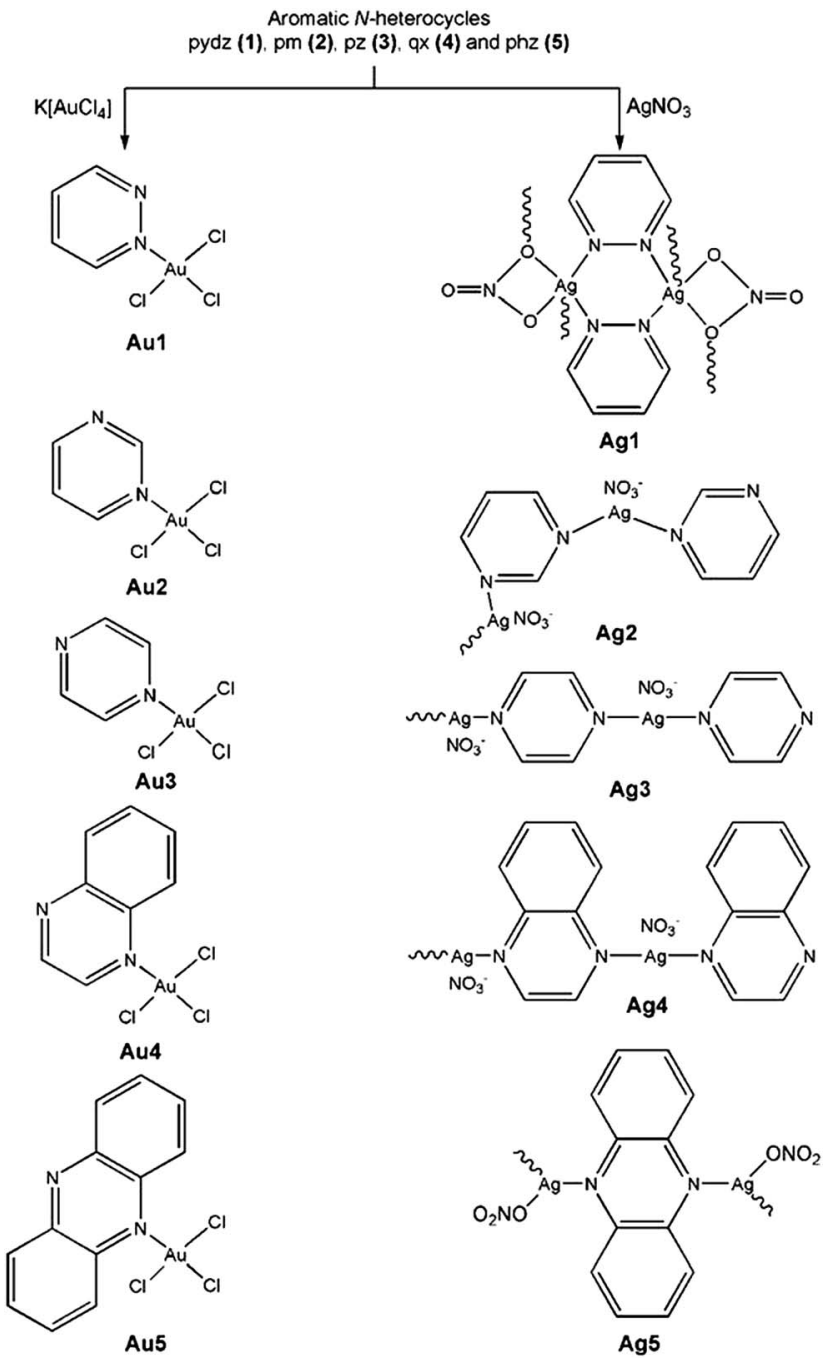

Scheme 1 Structural representation of gold(III) (Au1-5) and silver(I) (Ag1-5) complexes analyzed in this study (pydz = pyridazine, $\mathrm{pm}=$ pyrimidine, $\mathrm{pz}=$ pyrazine, $\mathrm{qx}=$ quinoxaline and phz = phenazine)

the oxygen atoms from nitrate anions. ${ }^{27}$ On the other hand, the Ag2 complex is a discrete tetracycle containing four $\mathrm{Ag}(\mathrm{I})$ ions and four pm ligands, in which each $\mathrm{Ag}(\mathrm{I})$ ion has a bent coordination geometry as a consequence of weak interaction with two nitrate anions. ${ }^{29}$ Both complexes Ag3 and Ag4, containing coordinated $\mathrm{pz}$ and $\mathrm{qx}$, respectively, are 1D coordination polymers with the characteristic linear two-coordination geometry of $\mathrm{Ag}(\mathrm{I})$ ion, ${ }^{26,30}$ while the Ag5 complex has trigonal planar geometry. The asymmetric unit of the latter complex comprises $\mathrm{Ag}(\mathrm{I})$ ion, a nitrate and half of a phz molecule. ${ }^{28}$

\section{Stability of Au1-5 and Ag1-5 complexes}

Solution stability. An essential prerequisite for the biological evaluation of metal complexes is their sufficient stability in solution. ${ }^{31,32}$ The solution behaviour of the Au1-5 and Ag1-5 complexes (Scheme 1) was analyzed by absorption UV-vis spectrophotometry. For this purpose, the Au1-5 and Ag1-5 complexes were dissolved in $\mathrm{DMF} / \mathrm{H}_{2} \mathrm{O}(1: 1, \mathrm{v} / \mathrm{v})$ and DMSO, respectively, and their UV-vis spectra were recorded directly after dissolution, as well as after $24 \mathrm{~h}$ of incubation at $37^{\circ} \mathrm{C}$. Dimethyl sulfoxide was not used for the dissolution of Au1-5, due to their decomposition to free aromatic N-heterocycles in this solvent. ${ }^{\mathbf{2 4 2 5}}$ On the other hand, all investigated silver(I) complexes were stable in DMSO solution, i.e. no coordination of this solvent to $\operatorname{Ag}(\mathrm{I})$ was observed during time based on the proton NMR spectroscopy. The wavelengths of maximum absorption for the Au1-5 and Ag1-5 complexes ( $\left.\lambda_{\max }, \mathrm{nm}\right)$, as well as molar extinction coefficients $\left(\varepsilon, \mathrm{M}^{-1} \mathrm{~cm}^{-1}\right)$, determined directly after dissolution of the complexes in the corresponding solvents, are listed in the Experimental section.

For most of the investigated gold(III) and silver(I) complexes, the observed transitions remained substantially unmodified over $24 \mathrm{~h}$ at $37{ }^{\circ} \mathrm{C}$, implying their stability in solution during this time. Nevertheless, a slight decrease in the intensity of the absorption maximum was noticed, although without significant modifications of spectrum shape. These minor changes might be ascribed either to release of the N-heterocyclic ligand from $\mathrm{Au}(\mathrm{III})$ and $\mathrm{Ag}(\mathrm{I})$ ions or to partial reduction of these ions to the metallic gold and silver, respectively. ${ }^{33}$

Air/light stability. In addition to the sufficient solution stability of the metal complexes evaluated as potential antimicrobial agents, their high air/light stability can be also of great importance for their possible external application in the form of ointments, gels and coating materials of dressings. ${ }^{34}$ In order to investigate the air/light stability of the Au1-5 and Ag1-5 complexes, sterile cellulose discs impregnated with stock solution of these complexes $\left(200 \mu \mathrm{g}\right.$ per disc, using $50 \mathrm{mg} \mathrm{mL^{-1 }}$ DMF and DMSO stock solution, respectively) were exposed to air and light at $37{ }^{\circ} \mathrm{C}$ and monitored within $96 \mathrm{~h}$. The obtained photos of the samples are presented in Fig. S1. $\dagger$ As can be seen, Au1-5 clearly showed better air/light stability than the corresponding Ag1-5 complexes. All investigated silver(I) complexes became darker after $24 \mathrm{~h}$, whereas the corresponding gold(III) complexes remained almost unaltered during this time, except the complex Au5 containing phz, which started to be a little beige in color. Moreover, the silver(I) complexes were almost completely dark after 96 h, except the Ag1 complex having coordinated pydz ligand. On the other hand, the slow light decomposition process was observed only for the Au5 complex.

\section{Antimicrobial and cytotoxic properties of Au1-5 and Ag1-5 complexes}

Gold(III) complexes Au1-5 and the corresponding Ag1-5 complexes were evaluated as antibacterial agents against two Gram-negative bacteria (Escherichia coli and Pseudomonas aeruginosa PAO1), two Gram-positive bacteria (Staphylococcus aureus and Lysteria monocytogenes) and the fungus Candida albicans (Table 1). All these microorganisms are human pathogens, which can cause and are associated with a variety of diseases such as skin, wound and burn infections, pneumonia, and infections of the central nervous system and urinary tract, as well as with nosocomial infections and infections of critically ill patients. ${ }^{35,36}$ The antimicrobial activity of Au1-5 and Ag1-5 and the starting compounds used for their synthesis, $\mathrm{K}\left[\mathrm{AuCl}_{4}\right]$ 
Table 1 Antimicrobial activities of Au1-5 and the corresponding Ag1-5 complexes in comparison to $\left.\mathrm{K}_{\mathrm{AuCl}}\right]$ and $\mathrm{AgNO}_{3}$, respectively, as $\mathrm{MIC}$ concentrations ( $\mu \mathrm{g} \mathrm{mL}^{-1}$ ). MIC values for all $\mathrm{N}$-heterocyclic ligands were $>250 \mu \mathrm{g} \mathrm{mL}^{-1}$

\begin{tabular}{|c|c|c|c|c|c|}
\hline Compound & $\begin{array}{l}\text { Pseudomonas } \\
\text { aeruginosa } \mathrm{PAO} 1\end{array}$ & $\begin{array}{l}\text { Escherichia } \\
\text { coli }\end{array}$ & $\begin{array}{l}\text { Staphylococcus } \\
\text { aureus }\end{array}$ & $\begin{array}{l}\text { Lysteria } \\
\text { monocytogenes }\end{array}$ & $\begin{array}{l}\text { Candida } \\
\text { albicans }\end{array}$ \\
\hline Au1 & $10 \pm 1$ & $15.6 \pm 0.8$ & $15.6 \pm 0.4$ & $100 \pm 6$ & $50 \pm 0.8$ \\
\hline Au2 & $15 \pm 1$ & $15.6 \pm 0.8$ & $15.6 \pm 0.5$ & $100 \pm 8$ & $200 \pm 3$ \\
\hline Ag2 & $2.5 \pm 0.1$ & $7.8 \pm 0.6$ & $15.6 \pm 0.5$ & $7.8 \pm 0.8$ & $15.6 \pm 0.8$ \\
\hline Au3 & $8 \pm 0.5$ & $16 \pm 0.6$ & $15.6 \pm 0.2$ & $100 \pm 4$ & $50 \pm 0.6$ \\
\hline Ag4 & $15.6 \pm 0.5$ & $15.6 \pm 0.4$ & $31.2 \pm 0.5$ & $7.8 \pm 0.4$ & $15.6 \pm 0.6$ \\
\hline Au5 & $30 \pm 4$ & $62.5 \pm 1$ & $62.5 \pm 2$ & $100 \pm 4$ & $250 \pm 4$ \\
\hline Ag5 & $7.8 \pm 4$ & $15.6 \pm 1$ & $31.2 \pm 2$ & $15.6 \pm 0.4$ & $31.2 \pm 0.9$ \\
\hline $\mathrm{K}\left[\mathrm{AuCl}_{4}\right]$ & $8 \pm 0.5$ & $31.2 \pm 0.8$ & $15.6 \pm 0.4$ & $100 \pm 5$ & $40 \pm 0.5$ \\
\hline $\mathrm{AgNO}_{3}$ & $3.1 \pm 0.1$ & $5 \pm 0.2$ & $2.5 \pm 0.2$ & $3.1 \pm 0.2$ & $50 \pm 3$ \\
\hline
\end{tabular}

and $\mathrm{AgNO}_{3}$, against the abovementioned strains is expressed as minimal inhibitory concentration (MIC, $\mu \mathrm{g} \mathrm{mL}^{-1}$ ) and compared to the effect on the viability on the human fibroblast cell line (MRC5), to properly evaluate the therapeutic index (Fig. 1).

The obtained results indicate that all tested gold(III) and silver(I) complexes exhibited excellent to good antibacterial activity against the investigated strains with MIC values in the range of 2.5 to $100 \mu \mathrm{g} \mathrm{mL}^{-1}$. None of the N-heterocyclic ligands were toxic towards the bacterial strains in concentrations up to $250 \mu \mathrm{g} \mathrm{mL}{ }^{-1}$. Expectedly, silver(I) complexes showed more

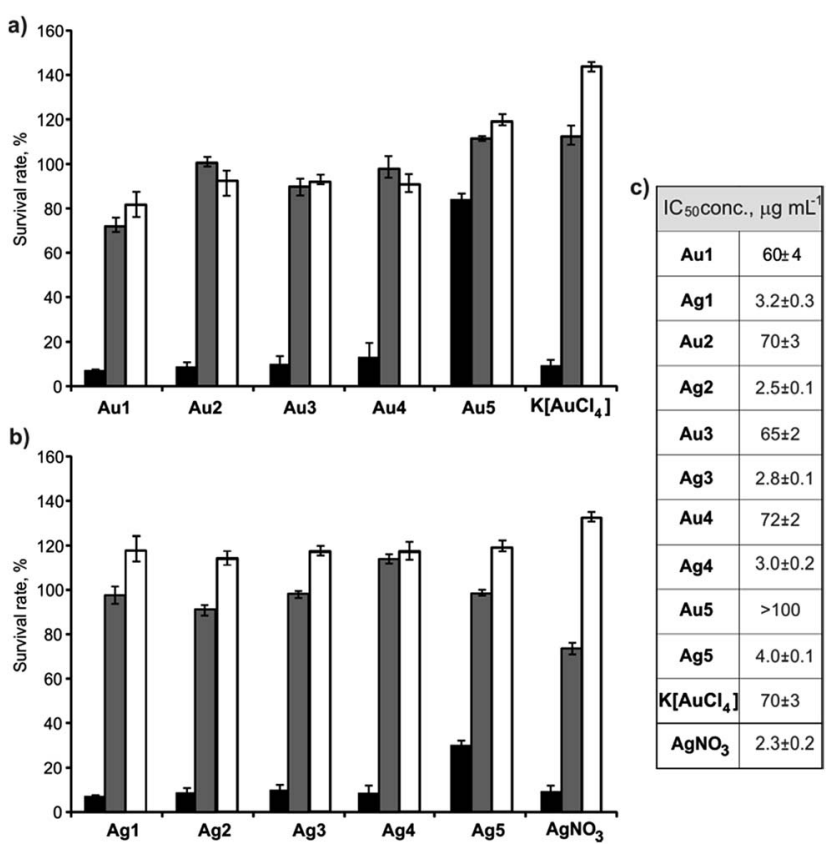

Fig. 1 In vitro antiproliferative effect of: (a) Au(III) complexes on human fibroblasts following $48 \mathrm{~h}$ exposure at a range of concentrations ( $\square-$ 10, $\square-50$ and $\mathbf{\square}-100 \mu \mathrm{g} \mathrm{mL}{ }^{-1}$ ); (b) $\mathrm{Ag}($ () complexes on human fibroblasts following $48 \mathrm{~h}$ exposure at a range of concentrations $(\square-1$, $\square-2$ and $\mathbf{\square}-5 \mathrm{~g} \mathrm{~mL}^{-1}$ ) and (c) calculated $\mathrm{IC}_{50}$ values against human fibroblast cell line (MRC5). potent antimicrobial properties in comparison to the corresponding gold(III) complexes, except in the case of Au4 and $S$. aureus (Table 1). The greatest difference was observable in the case of L. monocytogenes with the MICs of silver(I) compounds being generally 12.8 -fold lower in comparison to the corresponding gold(III) compounds.

Apart from the lower activity exhibited against L. monocytogenes and C. albicans, $\mathrm{Au}(\mathrm{III})$ complexes showed considerable activity against other bacterial strains with MIC values from 8 to $62.5 \mu \mathrm{g} \mathrm{mL}{ }^{-1}$. These values are quite comparable to the antimicrobial activity of other organometallic gold(III) complexes such as $\left[\mathrm{AuCl}_{2}(\mathrm{ppy})\right]$ (ppy is 2-phenylpyridine), ${ }^{37}$ and comparable or better than some gold(I) complexes containing $\mathrm{N}$ heterocyclic carbene ligands. ${ }^{6,38}$ The Au3 and Au1 exhibited the highest antimicrobial activity, while Au5 was the least active amongst all tested gold(III) complexes. From this, it can be concluded that the antimicrobial activity of the tested gold(III) complexes decreases with the increasing number of aromatic rings in the $\mathrm{N}$-heterocyclic ligands. The same was true for the corresponding silver(I) complexes, i.e. Ag4 and Ag5 containing bicyclic qx and tricyclic phz ligands, respectively, were slightly less active in comparison to the diazine-containing silver(I) complexes Ag1-3. The Ag1 and Ag2 exhibited similar antimicrobial activity profile with the pronounced activity against $P$. aeruginosa and MIC values of $2.5 \mu \mathrm{g} \mathrm{mL}{ }^{-1}$. As can be seen from Table 1, the antimicrobial activity of complexes was comparable to that of $\mathrm{K}\left[\mathrm{AuCl}_{4}\right]$ and $\mathrm{AgNO}_{3}$. However, it is important to note that the molar ratio of $\mathrm{Ag}(\mathrm{I})$ ion $\left(n\left(\mathrm{Ag}^{+}\right) / M_{\mathrm{r}}\right)$ in $\mathrm{AgNO}_{3}$ is considerably higher than in the silver(I) complexes, i.e. 1.47, 1.76 and 1.53-fold higher than in Ag1-3, Ag4 and Ag5, respectively. On the other hand, the difference in the molar ratio of $\mathrm{Au}(\mathrm{III})$ ion is not significant in the case of gold(III) complexes, being 1.01, 1.15 and 1.28-fold higher in $\mathrm{K}\left[\mathrm{AuCl}_{4}\right]$ than in Au1-3, Au4 and Au5, respectively.

The investigated $\mathrm{Au}(\mathrm{III})$ complexes exhibited much lower negative effects on the viability of the normal human lung fibroblast cell line MRC5 in comparison to Ag(I) complexes, which is a desirable property for application of these compounds as antibiotics (Fig. 1). In the case of the activity 
against $P$. aeruginosa PAO1, all Au(III) complexes exhibited therapeutic index $>3$, with the best being 8 for Au3. All of the tested Ag(I) compounds had negative therapeutic indexes, suggesting that their activity should be further exploited in the anticancer therapy or they can be used as antibiotics for external applications. In addition, these complexes can be further exploited in combination therapies and in infections closely associated with critically ill patients with cancer. As it was found previously, microorganisms and infections play major role in carcinogenesis, as well as in antitumor response. ${ }^{35,39-41}$ of the 12.7 million new cancer cases that occurred in 2008, around 2 million new cancer cases were attributable to the infections. ${ }^{39}$ Moreover, bacteremia is a major cause of life-threatening complications in patients with cancer, that are more vulnerable to invasive infection, due to ulcerative lesions in mucosal surfaces, immune suppression, neutropenia, mucositis and the use of invasive devices. Patients with cancer are also at extremely high risk for infections caused by the antibiotic resistant Gram-negative bacteria. ${ }^{35}$

According to the literature data, many silver(I) complexes with N-heterocyclic compounds have a strong antibacterial activity; however, their cytotoxicity has rarely been examined. The cytotoxic activity of $\left\{[\mathrm{Ag}(\mathrm{X})(\mathrm{phtz})]_{2}(\mu \text {-phtz })_{2}\right\} \quad\left(\mathrm{X}=\mathrm{NO}_{3}{ }^{-}\right.$, $\mathrm{CF}_{3} \mathrm{SO}_{3}{ }^{-}$and $\left.\mathrm{ClO}_{4}{ }^{-}\right),\left\{\left[\mathrm{Ag}\left(\mathrm{CF}_{3} \mathrm{SO}_{3}\right)(\mathrm{qz})\right]_{2}\right\}_{n}$ and $\left\{[\mathrm{Ag}(\mathrm{qz})]\left[\mathrm{BF}_{4}\right]\right\}_{n}$ against the human normal cell line MRC5 was moderate; therefore, these complexes could be further evaluated as possible antimicrobial agents. ${ }^{18}$ On the other hand, $\left[\mathrm{Ag}\left(\mathrm{NO}_{3}\right)\right.$ $(\mathrm{qz})]_{n}$ and $\left\{\left[\mathrm{Ag}\left(\mathrm{CH}_{3} \mathrm{CN}\right)\right]_{2}(\mu-\mathrm{phtz})_{2}\right\}\left[\mathrm{BF}_{4}\right]_{2}$ exhibited a negative effect on in vitro proliferation of the MRC5 cell line and also toxicity on zebrafish embryos, although significantly lower than that of $\mathrm{AgNO}_{3}$ and $\mathrm{AgBF}_{4}$ salts. ${ }^{42}$ Recently, Ortego et al. synthesized and characterized (aminophosphine)gold(I) and silver(I) complexes and evaluated them as antibacterial agents against Gram-negative Salmonella enterica serovar typhimurium and $E$. coli and Gram-positive L. monocytogenes and $S$. aureus. ${ }^{\mathbf{1 9}}$ They have observed moderate antimicrobial activity for all gold(I) complexes and the silver(I) derivatives without coordinated $\mathrm{PPh}_{3}$ groups and suggested that the inhibition of peptidoglycan synthesis in the cell wall may be the mechanism of action of these complexes because of their specific selectivity to the Gram-positive versus Gram-negative bacteria. They also highlighted the influence of the donor atoms coordinated to the metal center, however they did not examine cytotoxicity of these complexes. ${ }^{19}$ On the other hand, the cytotoxicity of gold(III) complexes towards MRC5 cell line has been previously examined, e.g. gold(III) complexes with the fluoroquinolones antimicrobial agents norfloxacin, levofloxacin and sparfloxacin have shown low cytotoxicity toward this cell line ( $\mathrm{IC}_{50}$ values in the range of $53-126 \mu \mathrm{M}),{ }^{43}$ as well as gold(III) complexes with L-histidine-containing peptides $\left(\mathrm{IC}_{50}>100 \mu \mathrm{M}\right)^{24}$ and with esters of $(S, S)$-ethylenediamine- $N, N^{\prime}$-di-2-propanoic acid $\left(\mathrm{IC}_{50}=\right.$ 23.15-97.88 $\mu \mathrm{M}) .^{44}$

Especially good activity observed against clinically important opportunistic pathogen $P$. aeruginosa PAO1, lead us to examine antibacterial potential of $\mathrm{Au}(\mathrm{III})$ and $\mathrm{Ag}(\mathrm{I})$ complexes in more detail. There are some recent reports that simple MIC testing overlooks potential interaction of tested compounds with serum proteins of the host, ${ }^{\mathbf{4 5}}$ and therefore we have examined the activity of the complexes in mammalian tissue culture media supplemented with fetal bovine serum vs. standard bacteriological media, and observed that serum does increase MIC values generally two-fold (Table S1 $\dagger$ ). This phenomenon does not occur in the case of Au3, Au5, Ag1 and Ag3-5 (Table S1 $\dagger$ ).

Biofilms represent a major threat during infections, so the ability to disrupt preformed biofilms is highly desirable trait of the novel antimicrobial agent. Indeed, all tested compounds exhibited the ability to disrupt $P$. aeruginos a preformed biofilms using both ATCC and clinical isolate to different extent. Ag(I) complexes were 2-3 fold more potent in dispersing biofilms in comparison to the corresponding Au(III) complexes, with Ag1 showing the best activity, followed by Ag4 and Ag5 (Fig. 2). On the other hand, Au1 was able to disrupt P. aeruginosa PAO1 biofilm to $15 \%$, while it was not as good towards clinical isolate, followed by Au2 with 60\% disruption (Fig. 2a). All other Au(III) complexes caused about $40 \%$ disruption of the preformed biofilms. Silver and silver-based compounds and materials have previously been shown to be effective in combating persistent and mature $P$. aeruginosa biofilms, whereby the concentration of silver(I) ions was found to be vital. ${ }^{46,47}$ On the other hand, this is the first report of the $\mathrm{Au}(\mathrm{III})$ complexes to be effective in the $P$. aeruginosa PAO1 preformed biofilms dispersal.

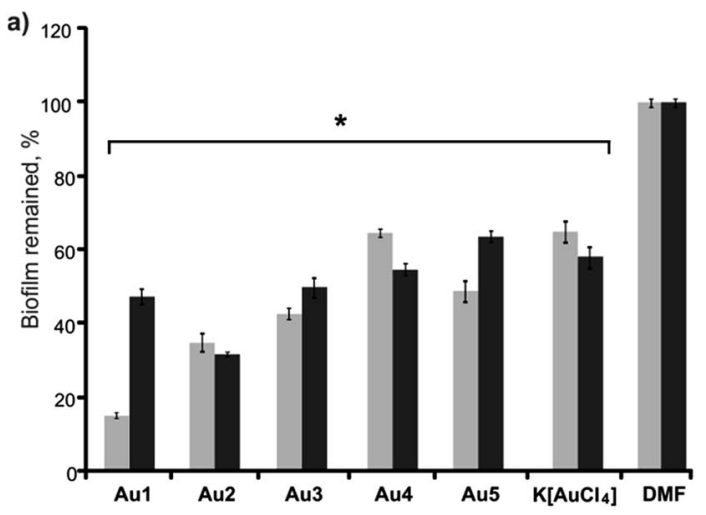

b)

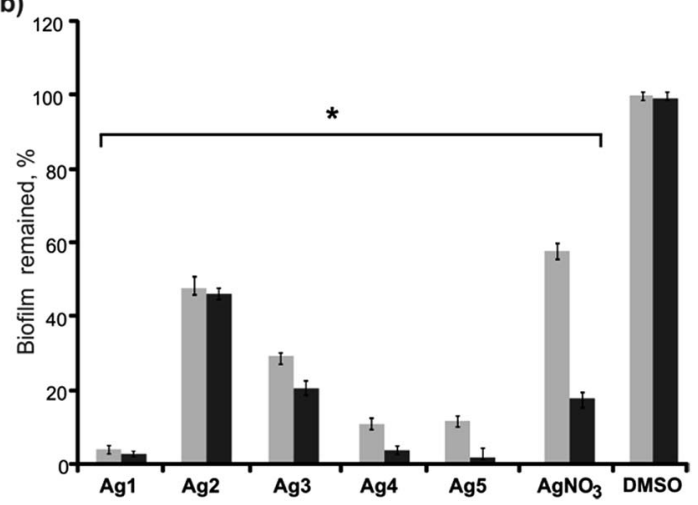

Fig. 2 Relative percentages showing biofilm disruption capabilities of the (a) gold(III) and (b) silver(I) complexes( $\square-P$. aeruginosa PAO1 biofilm; $-P$. aeruginosa DM-49 biofilm). Relative percentages were calculated upon comparing with the negative solvent vehicle control (DMF and DMSO). Values presented are mean values of four replicates of two independent experiments. 


\section{In vitro DNA interaction ability using $P$. aeruginosa gDNA}

DNA may be one of the primary targets of the examined complexes, as transition metal complexes, including $\mathrm{Au}(\mathrm{III})$ and $\operatorname{Ag}(\mathrm{I})$, are known to bind to DNA via both covalent and noncovalent interactions. ${ }^{48,49}$ In covalent binding, the labile ligand of a complex is replaced by a nitrogen base of DNA, such as guanine N7. Non-covalent DNA interactions include intercalative, electrostatic and groove (surface) binding of cationic metal complexes. ${ }^{50}$

The Ag1-4 and Ag1-5 complexes exhibited pronounced ability to competitively intercalate double stranded bacterial genomic DNA, which results in the inability of ethidium bromide to intercalate and emit under UV exposure (Fig. 3a and b). From the reduced emission intensity, visualized by gel electrophoresis, the most stable intercalation occurred with Ag1 and Ag2, and Au1 and Au3 (85-100\%), while other compounds intercalated between $50 \%$ and $80 \%$ relative to the solvent vehicle control (Fig. 3). The only complex that did not show this ability was Au5 (Fig. 3a).

This is in line with a mechanistic study of the antibacterial effect of silver(I) ions on E. coli and $S$. aureus, carried out by electron microscopy combined with X-ray microanalysis using $\mathrm{AgNO}_{3}{ }^{51}$ That study suggested an antibacterial mechanism of silver(I) through primary DNA interaction, which caused the loss of its replication ability and a general inactivation of sulfur containing proteins. On the other hand, it was suggested that the mechanism of action of gold-based compounds is DNAindependent, i.e. their interactions with DNA are not as tight as those found for the isostructural platinum(II) complexes, ${ }^{52}$

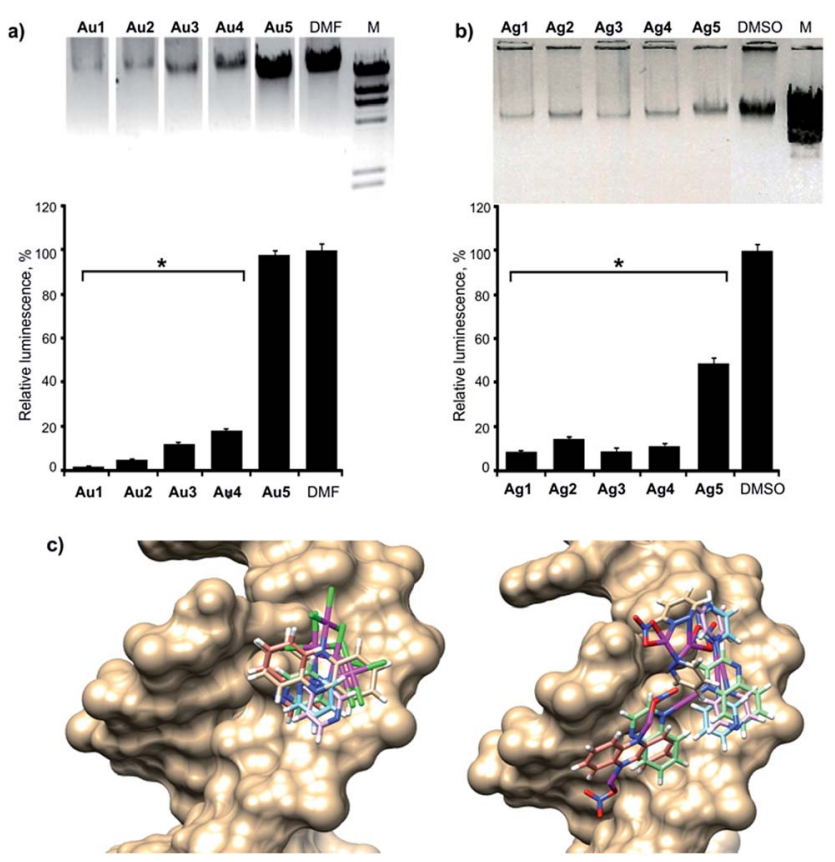

Fig. 3 In vitro interaction ability of (a) $A u($ (II) and (b) $A g($ (I) complexes with $P$. aeruginosa genomic DNA (results are considered significant when compared to the solvent control, $* p<0.01$ ); (c) computational docking model illustrating interactions between DNA and all studied complexes. Left - Au(III) complexes; Right - Ag(I) complexes. and that gold-protein interactions are responsible for their effects. ${ }^{53}$ Despite these facts, some gold(III) complexes, such as those with terpyridine derivatives ${ }^{54}$ and $\left[\mathrm{Au}\left(\right.\right.$ Gly-L-His- $\left.N, N^{\prime}, N^{\prime \prime}\right)$ $\mathrm{Cl}] \mathrm{Cl} \cdot 3 \mathrm{H}_{2} \mathrm{O}^{55}$ were found to target DNA in vitro.

DNA docking study. Molecular docking study was carried out to gain information about in silico DNA binding affinity for the studied gold(III) and silver(I) complexes. The predicted topranking pose with the complex lowest energy was applied for suggesting the best possible geometry of the complexes inside the DNA double helix and the highest binding affinity of DNA. MolDock score, docking score, Rerank score, Hbond score, van der Waals (vdW) score, steric interactions, vdW, Hbond and NonHBond interaction with DNA and ligand efficiency (LE) were used for evaluating interactions of complexes with DNA. Top ranked poses according to the used scoring functions are presented in Table 2.

The more negative the relative binding energy, greater the binding propensity of the complex with DNA, which can be correlated with the obtained experimental values for antibacterial activity. According to the obtained results for van der Waals interaction of complexes with DNA, among the studied gold(III) complexes the highest interaction energy has Au1 $\left(-811.422 \mathrm{kcal} \mathrm{mol}^{-1}\right)$, followed by Au3 (-810.903 $\left.\mathrm{kcal} \mathrm{mol}^{-1}\right)$ and Au2 (-751.458 kcal mol $\left.{ }^{-1}\right)$ and the lowest interaction was determined for Au5 (-15.804 kcal mol $\left.{ }^{-1}\right)$. All obtained results are in good correlation with the presented experimental results for MIC values and with their in vitro DNA intercalation ability. Furthermore, the obtained results for silver(I) complexes revealed that highest interaction energy has Ag1 (-605.265 kcal $\left.\mathrm{mol}^{-1}\right)$, followed by Ag4 (-275.394 kcal $\left.\mathrm{mol}^{-1}\right)$ and $\mathbf{A g} 2$ $\left(-169.154 \mathrm{kcal} \mathrm{mol}^{-1}\right)$ and the lowest interaction was determined for Ag3 $\left(-126.827 \mathrm{kcal} \mathrm{mol}^{-1}\right)$. Like for gold(III) complexes, the obtained results for silver(I) complexes are in good correlation with the presented experimental results for MIC values and with their in vitro DNA intercalation ability. Hydrogen bonds formed between complex and DNA are important for metal complex DNA binding and for further possible antibacterial activity. ${ }^{56,57}$ According to Hbond values, gold(III) complexes have higher interaction energies in comparison to silver(I) complexes. Also docking studies determined that Ag1 and Ag4 do not form hydrogen bonds with DNA.

The best poses for all studied complexes according to their values for van der Waals interaction with DNA are presented in Fig. 3c. The best docking pose for each studied complex individually is presented in Fig. S2 and $\mathrm{S} 3 . \dagger$ The minimum energy docked pose revealed that all complexes are very well fitted into the DNA major groove. Docking poses suggest that complexes and DNA base pairs are arranged in such way that they have effective $\pi-\pi$ stacking interactions. These interactions can lead to higher van der Waals interaction with the DNA functional groups which define the stability of groove making the AT regions more preferable regions of dodecamer. ${ }^{58}$ The investigated complexes exhibited additional stabilization through the strong intermolecular hydrogen bonding interaction between the C-2 carbonyl oxygen of $\mathrm{T}$ and the $\mathrm{N}-3$ nitrogen of $\mathrm{A}$. The best binding pose in the AT stretches of the minor groove was indicative of an extensive $\mathrm{H}$-bonding network. 
Table 2 Score values $\left(\mathrm{kcal} \mathrm{mol}^{-1}\right)$ for the studied complexes ${ }^{a}$

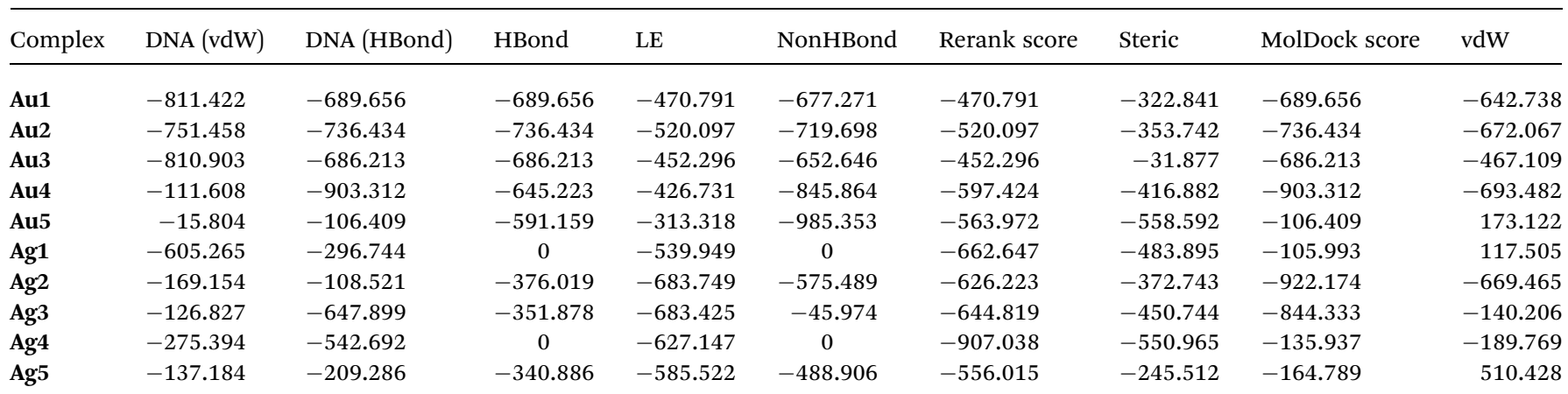

${ }^{a}$ LE - ligand efficiency calculated as MolDock score divided by heavy atoms count.

\section{Synergistic effect of $\mathrm{Au}(\mathrm{III})$ and $\mathrm{Ag}$ (I) complexes}

Clinicians often resort to combination therapy as a consequence of difficult-to-treat multi-resistant bacterial infections and or combination of diseases. ${ }^{59,60}$ Synergistic effects are often observable when combining antibiotics with different mode of action, such in the case of azithromycin and cationic antimicrobial peptides, that were effective against multidrug-resistant Gram-negative bacterial pathogens. ${ }^{45}$ Furthermore, nanosilver preparations were found to synergise in activity with chlorhexidine, resulting in bactericidal action towards two opportunistic wound pathogenic bacteria, P. aeruginosa and Staphylococcus epidermidis, ${ }^{61}$ while silver present in wound-dressing made bacteria more susceptible to the activity of antibiotics. ${ }^{47}$ More recently, synergy of silver nanoparticles and aztreonam against $P$. aeruginosa PAO1 biofilms was also reported. ${ }^{62}$

Prompted by these findings, we decided to test whether Ag1 as the most potent antimicrobial complex (Table 1) would have the synergistic effect on the activity of Au1 or Au3. Although Ag1 was less active toward the investigated bacterial strains than $\mathrm{AgNO}_{3}$, this silver(I) complex was less toxic on the normal human lung fibroblast cell line MRC5 (Table 1) and also on zebrafish embryos (Table 3; vide infra) than the silver(I) salt. Moreover, Ag1 was much more potent in disrupting the performed biofilms of $P$. aeruginosa strains in comparison to $\mathrm{AgNO}_{3}$ (Fig. 2). Due to the fact that the biological effect of complexes depends on the dissolution dynamics, we reasoned that mixing two complexes would be more suitable than complex and a salt. Considering these facts, we decided to

Table $3 \quad L_{50}$ values $\left(\mu \mathrm{g} \mathrm{mL}^{-1}\right.$ ) as derived from the concentrationresponse curves for gold(II) and silver(I) complexes and their mixtures in zebrafish toxicity assay at $114 \mathrm{hpf}$

\begin{tabular}{lc}
\hline Compound/mixture & $\mathrm{LC}_{50}\left(\mu \mathrm{g} \mathrm{mL}{ }^{-1}\right)$ \\
\hline AgNO $_{3}$ & 3.66 \\
Ag1 & 6.07 \\
Au3 & 9.22 \\
Au3/Ag1 6.4:1 & 13.66 \\
Au1/Ag1 $8: 1$ & 23.74 \\
Au1 & 24.25 \\
K[AuCl $]$ & 46.98
\end{tabular}

choose Ag1 complex instead of $\mathrm{AgNO}_{3}$. Using microdilution checkerboard method, we have shown that quarter of the MIC concentration of $\mathbf{A g} \mathbf{1}$ reduced the MIC of Au1 and Au3 by half, to $5 \mu \mathrm{g} \mathrm{mL}{ }^{-1}$ and $4 \mu \mathrm{g} \mathrm{mL}^{-1}$ respectively. Half MIC concentration of Ag1 (1.2 $\mu \mathrm{g} \mathrm{mL}^{-1}$ ) reduced MIC of Au3 four times (to $2 \mu \mathrm{g}$ $\mathrm{mL}^{-1}$ ). Based on the calculated fractional inhibitory concentration index of 0.75 for both mixtures containing Ag1, synergistic antimicrobial effect was confirmed (Fig. 4a), and we have decided to test two mixtures, Au1/Ag1 (8:1) and Au3/Ag1 (6.4 : 1), for $P$. aeruginosa antibiofilm activity, cytotoxicity and embryotoxicity. Both mixtures were confirmed to be able to efficiently disrupt preformed biofilms of $P$. aeruginosa PAO1, when used in MIC concentrations (Fig. S4†), while their cytotoxic profile was much improved in comparison to Ag1 (Fig. 4b). $\mathrm{IC}_{50}$ values of the mixtures were $50 \mu \mathrm{g} \mathrm{mL}{ }^{-1}$ and $55 \mu \mathrm{g} \mathrm{mL} \mathrm{m}^{-1}$ for Au1/Ag1 (8:1) and Au3/Ag1 (6.4:1) respectively, which improved selectivity index to $>10$. Furthermore, lower concentrations (2-25 $\mu \mathrm{g} \mathrm{mL}^{-1}$ ) of both mixtures did not affect cell morphology (Fig. 4c). Using this approach, we have confirmed that the antimicrobial synergies exist in the combination of silver(I) and gold(III) complexes, with the combined effects being greater than the sum of the individual effects, and that these synergies may be particularly effective in the treatment of biofilm-mediated infections. More importantly, toxicity was also modulated in a favorable manner.

The early study of Rhodes et al. also observed that copper(II) compounds and aurothiomalate were synergistic in their growth inhibitory effects towards Pseudomonas putida strains. ${ }^{63}$ However, to the best of our knowledge, there is no literature data on synergistic effects of the $\mathrm{Au}(\mathrm{III})$ and $\mathrm{Ag}$ (I) complexes. This may be due to the different mode of action or differential uptake mechanism of these two metal complexes. Based on these results it would be of interest to generate and assess dinuclear $\mathrm{Au}-\mathrm{Ag}$ complexes.

\section{Embryotoxicity of the selected $\mathrm{Au}(\mathrm{III})$ and $\mathrm{Ag}$ (I) complexes and their mixtures}

In order to investigate in vivo toxicity of the selected gold(III) and silver(I) complexes and their mixtures, we used zebrafish embryos and followed their survival and development upon the treatments with these compounds. Zebrafish are frequently 
a)

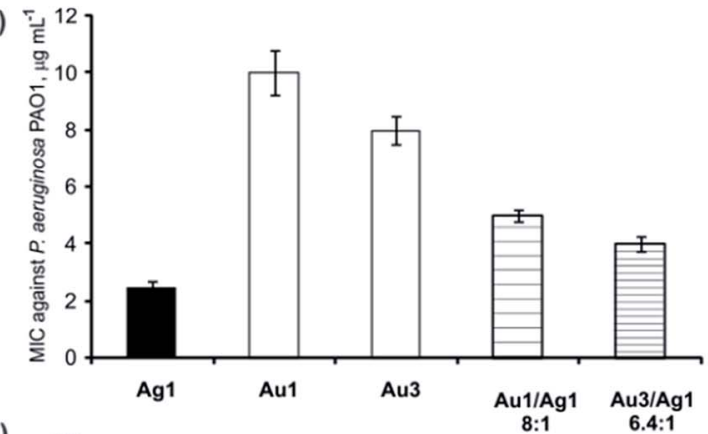

b)

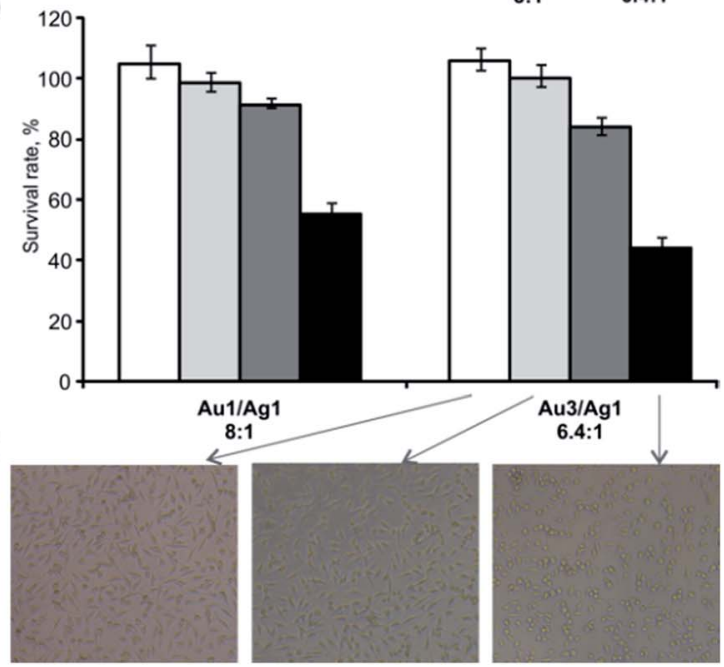

Fig. 4 Antimicrobial and cytotoxic profile of the investigated mixtures of gold(II) and silver(I) complexes in comparison to the single complexes. (a) MIC concentrations against $P$. aeruginosa PAO1 determined in microdilution broth assay; (b) MTT assay using ( $\mathbf{\square}-\mathbf{2}, \mathbf{\square}-$ $10, \boldsymbol{\square}-25$ and $-50 \mu \mathrm{g} \mathrm{mL}^{-1}$ ); and (c) morphological appearance of MRC5 cells upon treatment with mixture of Au3/Ag1 complex in $6.4: 1$ ratio.

used as in vivo vertebrate model for drug discovery and safety evaluation of pharmacologically active compounds due to their significant genetic similarity and very good correlation with humans in response to pharmaceuticals. ${ }^{\mathbf{6 4 , 6 5}}$ Also, their body transparency offers the possibility for visual inspection of all inner organs development upon applied treatments. As zebrafish embryos are normally hatched by 72 hours post fertilization (hpf), ${ }^{66}$ and some bioactive compound may impede this process and consequently reduce embryos' survival, the embryos development in this study was examined up to $114 \mathrm{hpf}$.

Obtained in vivo results revealed different toxicity profiling of the tested mixtures in response to their complexes (Table 3 and Fig. 5). While gold(III) and silver(I) complexes showed dose- and time-dependent mortality on zebrafish embryos, as well as teratogenic influences at each tested concentration, both $\mathrm{Au} / \mathrm{Ag}$ mixtures exerted only dose-dependent toxicity without teratogenicity signs at embryos that were alive. Based on $\mathrm{LC}_{50}$ values (Table 3), these compounds are ranked by their toxicity: $\mathrm{AgNO}_{3}$ $>$ Ag1 > Au3 > Au3/Ag1 6.4 : 1 > Au1/Ag1 $8: 1>$ Au1 > K[AuCl 4 .

None embryos survived at $50 \mu \mathrm{g} \mathrm{mL} \mathrm{m}^{-1}$ of any of the tested compounds. The treatment with $10-25 \mu \mathrm{g} \mathrm{mL}{ }^{-1}$ of complex Au3 prevented hatching of all alive zebrafish embryos, resulting in mortality of majority of them during period from 96 to $114 \mathrm{hpf}$ (Fig. 5a). Otherwise, hatching process is primarily biochemical process driven by Zn-metalloproteases, which function may be disrupted by chemical stress. ${ }^{67}$ As control embryos hatched up to $72 \mathrm{hpf}$, the prevention of embryos hatching under Au3 treatment was probably achieved by inhibition of the hatching enzymes, since alive embryos stayed unhatched up to $114 \mathrm{hpf}$. Recently, Lin et al. demonstrated that some free metal ions released from metal-oxide nanoparticles could bind to enzyme's active site and thus inhibited metalloprotease activity and hatching success. ${ }^{68}$

All alive embryos upon the exposure to Ag1 complex developed serious skeletal abnormalities (scoliosis, smaller head, jaw deformities; Fig. 5b), while embryos treated with Au1 complex at concentrations higher than $5 \mu \mathrm{g} \mathrm{mL}^{-1}$ showed heartbeat disturbance, with significantly increased heartbeat rate (data not shown). However, Au1 was the least toxic metal complex tested on zebrafish, with $\mathrm{LC}_{50}$ value of $24.25 \mu \mathrm{g} \mathrm{mL}^{-1}$ (Table 3). Importantly, the mixtures Au1/Ag1 $8: 1$ and Au3/Ag1 6.4:1, which showed higher antimicrobial bioactivity then tested complexes on their own (Fig. 4a) and improved cytotoxicity profile (Fig. 4b), did not show any adverse effect on embryos' development, heartbeat rate and hatching (Fig. 5b). The embryos treated with $\mathrm{AgNO}_{3}$, which was used for the synthesis of silver(I) complexes, had lethal outcome at each tested concentration up to $114 \mathrm{hpf}$, whereas alive embryos (4\%) have only been detected upon treatment with $5 \mu \mathrm{g} \mathrm{mL}{ }^{-1}$, and were seriously teratogenic (Table $\mathrm{S} 2 \dagger$ ). Results obtained upon $\mathrm{AgNO}_{3}$ exposure are in line with the literature data, where low dose of $\mathrm{AgNO}_{3}$ were documented to be lethal for zebrafish embryos. ${ }^{69}$ On the other hand, $\mathrm{K}\left[\mathrm{AuCl}_{4}\right]$, which was used for the synthesis of gold(III) complexes and is not being used in the clinical practice, exerted low toxicity on zebrafish embryos (Table S2 $\dagger$ ), as well as low in vitro cytotoxic activity. The literature data on embryotoxicity of gold(III) complexes is limited, but previous studies did show that $\left[N-\left(N^{\prime}, N^{\prime}\right.\right.$-dimethylaminoethyl)-1,8-naphthalimide-4-sulfide](triethylphosphine)gold(I) complex can possess significant anti-angiogenic potential in the development of zebrafish embryos. ${ }^{70}$

\section{Experimental}

\section{Materials}

Distilled water was demineralized and purified to a resistance of greater than $10 \mathrm{M} \Omega \mathrm{cm}^{-1}$. Potassium tetrachloridoaurate(III) $\left(\mathrm{K}\left[\mathrm{AuCl}_{4}\right]\right)$, silver(I) nitrate $\left(\mathrm{AgNO}_{3}\right)$ pyridazine, pyrimidine, pyrazine, quinoxaline, phenazine, ethanol, acetonitrile dichloromethane, deuterated acetone and dimethyl sulfoxide were purchased from the Sigma-Aldrich. All the employed chemicals were of analytical reagent grade and used without further purification.

\section{Synthesis of the gold(III) and silver(I) complexes with aromatic $\mathbf{N}$-heterocycles}

Gold(III) and silver(I) complexes with aromatic N-heterocycles, pyridazine (pydz, 1), pyrimidine (pm, 2), pyrazine (pz, 3), 


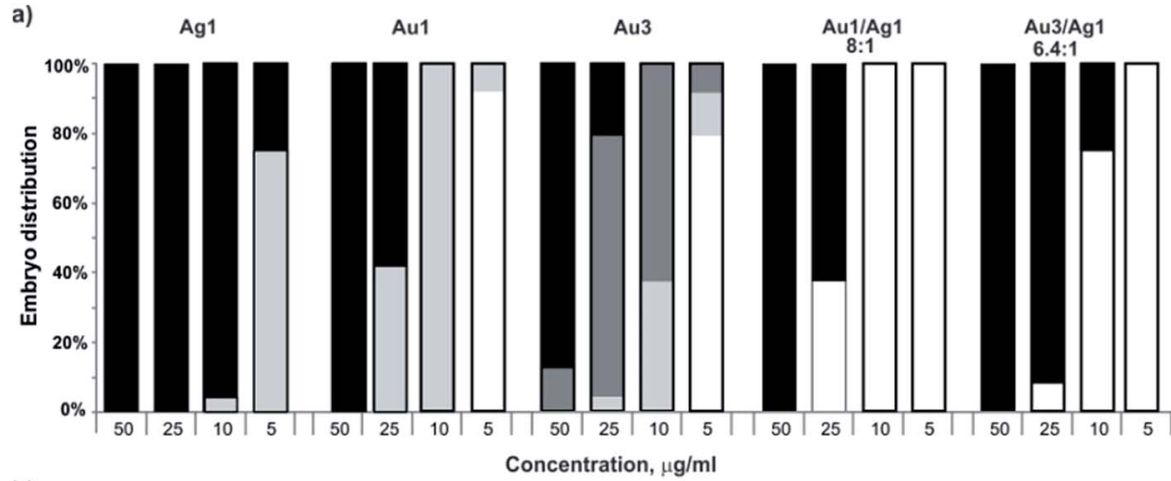

b)

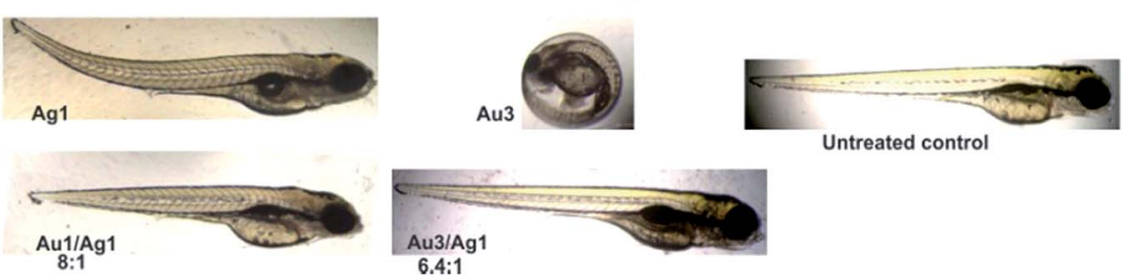

Fig. 5 Comparison of toxicity of silver(I) complex (Ag1) and gold(II) complexes (Au1 and Au3) with their two mixtures (Au1/Ag1 $8: 1$ and Au3/Ag1 6.4 : 1) on development of zebrafish embryos after $114 \mathrm{hpf}$ exposure to the different concentrations. (a) Embryo distribution: $\square-$ normal and hatched embryos, $\mathbf{-}$ - embryos died up to $96 \mathrm{hpf}, \boldsymbol{\square}$ - unhatched larvae which dead in period from 96 hpf to $114 \mathrm{hpf}$, and $\square-$ teratogenic embryos. (b) Images of zebrafish embryos at $114 \mathrm{hpf}$ after the treatments with gold(II) and silver(I) complexes and their mixtures. Embryos treated with: $5 \mu \mathrm{g} \mathrm{mL}^{-1}$ of Ag1 had scoliosis, head and snout deformations; $25 \mu \mathrm{g} \mathrm{mL}^{-1}$ of Au3 were prevented for hatching and mostly died up to 114 hpf; $25 \mu \mathrm{g} \mathrm{mL} \mathrm{L}^{-1}$ of Au1/Ag1 $8: 1$ and $10 \mu \mathrm{g} \mathrm{mL}^{-1}$ of Au3/Ag1 6.4:1 were without teratogenicity signs; and untreated embryos.

quinoxaline (qx, 4) and phenazine (phz, 5), were synthesized by modification of the previously described methods. ${ }^{24-27}$

Gold(III) complexes (Au1-5). The solution of $0.25 \mathrm{mmol}$ of the corresponding aromatic N-heterocycles, $18.5 \mu \mathrm{L}$ of $98 \%$ pydz, $19.9 \mu \mathrm{L}$ of $99 \% \mathrm{pm}, 20.0 \mathrm{mg}$ of pz, $32.5 \mathrm{mg}$ of qx and $45.0 \mathrm{mg}$ of phz in $1.0 \mathrm{~mL}$ of ethanol was added slowly under stirring to the solution containing an equimolar amount of $\mathrm{K}\left[\mathrm{AuCl}_{4}\right](94.5 \mathrm{mg}$ in $5.0 \mathrm{~mL}$ of water). The yellow precipitate, formed immediately after addition of the N-heterocyclic ligand, was filtered off, washed with water, and recrystallized in dichloromethane to form yellow crystals of gold(III) complexes. The crystals were collected from the solution and dried in the dark at ambient temperature. The yield was $92 \%$ for $\left[\mathrm{AuCl}_{3}(\mathrm{pydz})\right]$ (Au1) (88.2 $\mathrm{mg}), 83 \%$ for $\left[\mathrm{AuCl}_{3}(\mathrm{pm})\right](\mathbf{A u 2})(79.6 \mathrm{mg}), 85 \%$ for $\left[\mathrm{AuCl}_{3}(\mathrm{pz})\right]$ (Au3) $(81.5 \mathrm{mg}), 65 \%$ for $\left[\mathrm{AuCl}_{3}\right.$ (qx)] (Au4) $(70.4 \mathrm{mg}$ ) and $89 \%$ for $\left[\mathrm{AuCl}_{3}(\mathrm{phz})\right]$ (Au5) (107.6 mg). All complexes were pure based on elemental microanalysis and NMR $\left({ }^{1} \mathrm{H}\right.$ and $\left.{ }^{13} \mathrm{C}\right)$ spectroscopy. The obtained NMR spectroscopic results were in accordance with those previously reported for the same complexes. ${ }^{24,25}$

Anal. calcd for Au1 $=\mathrm{C}_{4} \mathrm{H}_{4} \mathrm{AuCl}_{3} \mathrm{~N}_{2}\left(M_{\mathrm{r}}=383.41\right)$ : C, 12.53\%; H, $1.05 \%$; N, 7.31\%. Found: C, 12.87\%; H, 1.21\%; N, 7.57\%. ${ }^{1} \mathrm{H}$ NMR (400 MHz, $\left.\mathrm{CD}_{3} \mathrm{COCD}_{3}\right): \delta=8.45(d d d, J=8.2,4.9,1.5 \mathrm{~Hz}$, $1 \mathrm{H}), 8.60(d d d, J=8.2,5.7,2.1 \mathrm{~Hz}, 1 \mathrm{H}), 9.51(d d d, J=4.9,2.1,1.0$ $\mathrm{Hz}, 1 \mathrm{H}), 9.92 \mathrm{ppm}(d d d, J=5.7,1.5,1.0 \mathrm{~Hz}, 1 \mathrm{H}) .{ }^{13} \mathrm{C} \mathrm{NMR}(101$ $\left.\mathrm{MHz}, \mathrm{CD}_{3} \mathrm{COCD}_{3}\right): \delta=135.1,136.5,156.5,156.6 \mathrm{ppm}$. IR $(\mathrm{KBr}, \nu$, $\left.\mathrm{cm}^{-1}\right)$ : 3430(br), 3093(m), 3081(m), 1632(m), 1567(m), 1455(m), 1398(vs.), 1299(m), 1221(w), 1153(w), 1058(w), 975(s), 774(vs.), $727(\mathrm{~m}), 687(\mathrm{w}), 642(\mathrm{w}), 472(\mathrm{w}) . \mathrm{UV}$-vis $\left(\mathrm{DMF} / \mathrm{H}_{2} \mathrm{O}, \lambda_{\max }, \mathrm{nm}\right)$ : $298.0\left(\varepsilon=6.9 \times 10^{2} \mathrm{M}^{-1} \mathrm{~cm}^{-1}\right)$.

Anal. calcd for $\mathrm{Au2}=\mathrm{C}_{4} \mathrm{H}_{4} \mathrm{AuCl}_{3} \mathrm{~N}_{2}\left(M_{\mathrm{r}}=383.41\right)$ : C, 12.53\%; $\mathrm{H}, 1.05 \%$; N, 7.31\%. Found: C, $12.96 \%$; H, 1.14\%; N, 7.13\%. ${ }^{1} \mathrm{H}$
NMR $\left(400 \mathrm{MHz}, \mathrm{CD}_{3} \mathrm{COCD}_{3}\right): \delta=8.19(d d d, J=6.1,4.9,1.1 \mathrm{~Hz}$, $1 \mathrm{H}), 9.32(d d, J=4.9,2.0 \mathrm{~Hz}, 1 \mathrm{H}), 9.51(d d d, J=6.1,2.0,1.3 \mathrm{~Hz}$, 1H), $9.79 \mathrm{ppm}$ (brs, $1 \mathrm{H}) .{ }^{13} \mathrm{C} \mathrm{NMR}\left(101 \mathrm{MHz}, \mathrm{CD}_{3} \mathrm{COCD}_{3}\right): \delta=$ 125.2, 157.6, 158.0, $162.6 \mathrm{ppm}$. IR (KBr, $\left.\nu, \mathrm{cm}^{-1}\right)$ : 3437(br), 3095(m), 3070(m), 1637(w), 1591(s), 1552(m), 1465(m), 1412(vs.), 1177(w), 1133(w), 1084(w), 1062(m), 951(w), 819(m), 693(s), 641(m), 472(w). UV-vis (DMF/ $\left.\mathrm{H}_{2} \mathrm{O}, \lambda_{\max }, \mathrm{nm}\right): 296.0(\varepsilon=$ $\left.6.4 \times 10^{2} \mathrm{M}^{-1} \mathrm{~cm}^{-1}\right)$.

Anal. calcd for $\mathrm{Au3}=\mathrm{C}_{4} \mathrm{H}_{4} \mathrm{AuCl}_{3} \mathrm{~N}_{2}\left(M_{\mathrm{r}}=383.41\right)$ : C, 12.53\%; $\mathrm{H}, 1.05 \%$; N, 7.31\%. Found: C, 12.69\%; H, 1.12\%; N, 7.15\%. ${ }^{1} \mathrm{H}$ NMR (400 MHz, $\left.\mathrm{CD}_{3} \mathrm{COCD}_{3}\right): \delta=9.30 \mathrm{ppm}\left(\mathrm{AA}^{\prime} \mathrm{BB}^{\prime}, 4 \mathrm{H}\right) .{ }^{13} \mathrm{C}$ NMR (101 MHz, $\mathrm{CD}_{3} \mathrm{COCD}_{3}$ ): $\delta=145.0,151.2 \mathrm{ppm}$. IR (KBr, $\nu$, $\left.\mathrm{cm}^{-1}\right)$ : 3446(br), 3121(m), 3104(m), 1636(w), 1584(w), 1417(vs.), 1225(w), 1167(m), 1122(m), 1073(m), 1015(w), 798(s), 725(w), 472(m). UV-vis $\left(\mathrm{DMF} / \mathrm{H}_{2} \mathrm{O}, \lambda_{\max }, \mathrm{nm}\right): 296.0\left(\varepsilon=1.0 \times 10^{3} \mathrm{M}^{-1}\right.$ $\left.\mathrm{cm}^{-1}\right)$.

Anal. calcd for $\mathrm{Au4}=\mathrm{C}_{8} \mathrm{H}_{6} \mathrm{AuCl}_{3} \mathrm{~N}_{2}\left(M_{\mathrm{r}}=433.46\right)$ : C, $22.17 \%$; $\mathrm{H}, 1.40 \%$; N, 6.46\%. Found: C, 22.45\%; H, 1.58\%; N, 6.49\%. ${ }^{1} \mathrm{H}$ NMR (400 MHz, $\left.\mathrm{CD}_{3} \mathrm{COCD}_{3}\right): \delta=8.27(d d d, J=8.2,7.1,1.2 \mathrm{~Hz}$, $1 \mathrm{H}), 8.38(d d d, J=8.6,7.1,1.4 \mathrm{~Hz}, 1 \mathrm{H}), 8.48(d d d, J=8.2,1.4,0.7$ $\mathrm{Hz}, 1 \mathrm{H}), 8.90(d d d, J=8.6,1.2,0.7 \mathrm{~Hz}, 1 \mathrm{H}), 9.57(d, J=2.7 \mathrm{~Hz}$, $1 \mathrm{H}), 9.84 \mathrm{ppm}(d, J=2.7 \mathrm{~Hz}, 1 \mathrm{H}) .{ }^{13} \mathrm{C} \mathrm{NMR}\left(101 \mathrm{MHz}, \mathrm{CD}_{3^{-}}\right.$ $\left.\mathrm{COCD}_{3}\right): \delta=127.2,131.5,134.2,135.5,137.5,147.1,147.8,149.5$ ppm. IR (KBr, $\left.\nu, \mathrm{cm}^{-1}\right)$ : 3400(br), 3064(w), 1610(w), 1579(w), 1500(vs.), 1465(m), 1423(w), 1384(w), 1355(vs.), 1293(w), 1269(w), 1220(m), 1207(m), 1147(m), 1136(m), 1045(m), 971(m), 870(s), 849(m), 780(m), 752(s), 654(w), 538(w), 530(w). UV-vis $\left(\mathrm{DMF} / \mathrm{H}_{2} \mathrm{O}, \lambda_{\max }, \mathrm{nm}\right): 316.0\left(\varepsilon=2.1 \times 10^{3} \mathrm{M}^{-1} \mathrm{~cm}^{-1}\right)$.

Anal. calcd for Au5 $=\mathrm{C}_{12} \mathrm{H}_{8} \mathrm{AuCl}_{3} \mathrm{~N}_{2}\left(M_{\mathrm{r}}=483.52\right): \mathrm{C}$, $29.81 \%$; H, 1.67\%; N, 5.79\%. Found: C, 30.02\%; H, 1.60\%; N, $5.91 \% .{ }^{1} \mathrm{H}$ NMR $\left(400 \mathrm{MHz}, \mathrm{CD}_{3} \mathrm{COCD}_{3}\right): \delta=8.34(d d d, J=8.7$, 
$6.8,1.1 \mathrm{~Hz}, 2 \mathrm{H}), 8.58(d d d, J=8.9,6.8,1.3 \mathrm{~Hz}, 2 \mathrm{H}), 8.65(d d d, J=$ $8.7,1.3,0.6 \mathrm{~Hz}, 2 \mathrm{H}), 9.19 \mathrm{ppm}(d d d, J=8.9,1.1,0.6 \mathrm{~Hz}, 2 \mathrm{H}) .{ }^{13} \mathrm{C}$ NMR (101 MHz, $\left.\mathrm{CD}_{3} \mathrm{COCD}_{3}\right): \delta=126.1,131.9,133.5,138.4$, 147.5 ppm. IR (KBr, $\left.\nu, \mathrm{cm}^{-1}\right)$ : 3435(br), 3053(w), 2923(w), 2852(w), 1618(w), 1598(w), 1521(m), 1470(s), 1432(m), 1384(w), 1352(m), 1285(w), 1230(w), 1173(w), 1127(s), 836(m), 749(vs.), 662(w), 594(s), 524(w). UV-vis (DMF/ $\left.\mathrm{H}_{2} \mathrm{O}, \lambda_{\max }, \mathrm{nm}\right): 368.0(\varepsilon=$ $\left.4.4 \times 10^{2} \mathrm{M}^{-1} \mathrm{~cm}^{-1}\right)$.

Silver(I) complexes (Ag1-5). The solution of $2.0 \mathrm{mmol}$ of $\mathrm{AgNO}_{3}(339.7 \mathrm{mg})$ in $5.0 \mathrm{~mL}$ of ethanol was added slowly under stirring to the solution containing an equimolar amount of the corresponding N-heterocycle $(148.2 \mu \mathrm{L}$ of $98 \%$ pydz, $159.2 \mu \mathrm{L}$ of $99 \% \mathrm{pm}, 160.2 \mathrm{mg}$ of pz, $260.3 \mathrm{mg}$ of qx and $360.4 \mathrm{mg}$ of phz) dissolved in $20.0 \mathrm{~mL}$ of warm ethanol. The reaction mixture was stirred in the dark at room temperature for $3 \mathrm{~h}$. The solid product of Ag1-5 complexes precipitated during this time was filtered off and dissolved in $20.0 \mathrm{~mL}$ of acetonitrile. The complexes were crystallized after acetonitrile solutions were left to stand in the refrigerator at $+4{ }^{\circ} \mathrm{C}$ for four days. The colorless crystals of Ag1-4 and yellow crystals of Ag5 were collected from the solution and dried in the dark at ambient temperature. Yield: $440.0 \mathrm{mg}(88 \%)$ for $\left\{\left[\mathrm{Ag}\left(\mathrm{NO}_{3}\right)\right]_{2}(\mu-\mathrm{pydz})_{2}\right\}_{n}$ (Ag1), $399.9 \mathrm{mg}$ $(80 \%)$ for $\left\{[\mathrm{Ag}(\mathrm{pm})]\left(\mathrm{NO}_{3}\right)\right\}_{n} \quad(\mathbf{A g} 2), 419.9 \mathrm{mg} \quad(84 \%)$ for $\left\{[\mathrm{Ag}(\mathrm{pz})]\left(\mathrm{NO}_{3}\right)\right\}_{n}$ (Ag3), $468.0 \mathrm{mg}(78 \%)$ for $\left\{[\mathrm{Ag}(\mathrm{qz})]\left(\mathrm{NO}_{3}\right)\right\}_{n}(\mathbf{A g} 4)$ and $462.7 \mathrm{mg}(89 \%)$ for $\left\{\left[\mathrm{Ag}\left(\mathrm{NO}_{3}\right)\right]_{2}(\mu-\mathrm{phz})\right\}_{n}$ (Ag5). All complexes were pure based on elemental microanalysis and NMR $\left({ }^{1} \mathrm{H}\right.$ and $\left.{ }^{13} \mathrm{C}\right)$ spectroscopy.

Anal. calcd for $\mathbf{A g 1}=\mathrm{C}_{4} \mathrm{H}_{4} \mathrm{AgN}_{3} \mathrm{O}_{3}\left(M_{\mathrm{r}}=249.96\right)$ : C, 19.22\%; H, 1.61\%; N, 16.81\%. Found: C, 19.26\%; H, 1.76\%; N, 17.03\%. ${ }^{1} \mathrm{H}$ NMR (200 MHz, DMSO): $\delta=7.76(d d, J=3.8,3.2 \mathrm{~Hz}, 2 \mathrm{H})$, $9.25 \mathrm{ppm}(d d, J=3.8,3.2 \mathrm{~Hz}, 2 \mathrm{H}) .{ }^{13} \mathrm{C}$ NMR (50 MHz, DMSO): $\delta=127.6,152.4$ ppm. IR (KBr, $\left.\nu, \mathrm{cm}^{-1}\right): 3430(\mathrm{br}), 3059(\mathrm{~m})$, 1646(w), 1570(m), 1414(vs.), 1384(vs.), 1286(m), 1122(w), 1084(w), 1063(m), 966(m), 825(m), 761(m), 717(w), 667(m), 626(w). UV-vis (DMSO, $\left.\lambda_{\max }, \mathrm{nm}\right): 322.0\left(\varepsilon=3.1 \times 10^{2} \mathrm{M}^{-1}\right.$ $\left.\mathrm{cm}^{-1}\right)$.

Anal. calcd for $\mathrm{Ag} 2=\mathrm{C}_{4} \mathrm{H}_{4} \mathrm{AgN}_{3} \mathrm{O}_{3}\left(M_{\mathrm{r}}=249.96\right)$ : C, 19.22\%; H, 1.61\%; N, 16.81\%. Found: C, 19.18\%; H, 1.62\%; N, 17.10\%. ${ }^{1} \mathrm{H}$ NMR (200 MHz, DMSO): $\delta=7.58(t d, J=5.0,1.5 \mathrm{~Hz}, 1 \mathrm{H})$, 8.78-8.88 $(m, 2 \mathrm{H}), 9.20 \mathrm{ppm}(s, 1 \mathrm{H}) .{ }^{13} \mathrm{C}$ NMR (50 MHz, DMSO): $\delta=122.3,157.5,158.8$ ppm. IR (KBr, $\left.\nu, \mathrm{cm}^{-1}\right): 3480(\mathrm{br})$, $3085(\mathrm{~m}), \quad 1763(\mathrm{w}), 1571(\mathrm{~s}), 1399(v s),. 1383(v s), 1226(\mathrm{~m})$, $1177(\mathrm{w}), 1160(\mathrm{w}), 1067(\mathrm{w}), 825(\mathrm{~s}), 720(\mathrm{~m}), 647(\mathrm{w}), 625(\mathrm{w})$. UV-vis (DMSO, $\left.\lambda_{\max }, \mathrm{nm}\right): 294.0\left(\varepsilon=2.2 \times 10^{2} \mathrm{M}^{-1} \mathrm{~cm}^{-1}\right.$ ).

Anal. calcd for $\mathbf{A g} 3=\mathrm{C}_{4} \mathrm{H}_{4} \mathrm{AgN}_{3} \mathrm{O}_{3}\left(M_{\mathrm{r}}=249.96\right)$ : C, 19.22\%; $\mathrm{H}, 1.61 \%$; N, 16.81\%. Found: C, 19.16\%; H, 1.61\%; N, 17.11\%. ${ }^{1} \mathrm{H}$ NMR (200 MHz, DMSO): $\delta=8.67 \mathrm{ppm}(s, 4 \mathrm{H}) .{ }^{13} \mathrm{C}$ NMR $(50$ MHz, DMSO): $\delta=145.4$ ppm. IR (KBr, $\left.\nu, \mathrm{cm}^{-1}\right): 3445(\mathrm{br})$, 3082(w), 3045(w), 1494(w), 1384(vs.), 1154(m), 1132(w), 1081(w), 1054(m), 1023(m), 990(w), 825(m), 805(m). UV-vis (DMSO, $\lambda_{\max }$, $\mathrm{nm}): 320.0\left(\varepsilon=4.3 \times 10^{2} \mathrm{M}^{-1} \mathrm{~cm}^{-1}\right)$.

Anal. calcd for $\mathbf{A g} 4=\mathrm{C}_{8} \mathrm{H}_{6} \mathrm{AgN}_{3} \mathrm{O}_{3}\left(M_{\mathrm{r}}=300.02\right)$ : C, 32.03\%; H, 2.02\%; N, 14.01\%. Found: C, 32.02\%; H, 2.07\%; N, 14.21\%. ${ }^{1} \mathrm{H}$ NMR (200 MHz, DMSO): $\delta=7.84-7.94(m, 2 \mathrm{H}), 8.07-8.18(\mathrm{~m}$, $2 \mathrm{H}), 8.97 \mathrm{ppm}(s, 2 \mathrm{H}) .{ }^{13} \mathrm{C}$ NMR (50 MHz, DMSO): $\delta=129.3$, 130.4, 142.4, 145.9 ppm. IR (KBr, $\left.\nu, \mathrm{cm}^{-1}\right)$ : 3611(br), 3080(w), 3048(w), 3015(w), 1767(w), 1738(w), 1629(w), 1611(w), 1582(w), 1498(m), 1457(w), 1421(m), 1384(vs.), 1361(vs.), 1307(m), 1206(m), 1138(m), 1125(m), 1070(w), 1038(m), 954(m), 868(m), 850(m), 767(m), 756(m), 716(m), 659(w), 628(w), 609(w), 535(w), 513(w). UV-vis (DMSO, $\left.\lambda_{\max }, \mathrm{nm}\right): 316.0\left(\varepsilon=3.1 \times 10^{3} \mathrm{M}^{-1}\right.$ $\left.\mathrm{cm}^{-1}\right)$.

Anal. calcd for Ag5 $=\mathrm{C}_{12} \mathrm{H}_{8} \mathrm{Ag}_{2} \mathrm{~N}_{4} \mathrm{O}_{6}\left(M_{\mathrm{r}}=519.95\right): \mathrm{C}$, $27.72 \%$; H, 1.55\%; N, 10.78\%. Found: C, 27.92\%; H, 1.65\%; N, 10.55\%. ${ }^{1} \mathrm{H}$ NMR (200 MHz, DMSO): $\delta=7.92-8.04(m, 4 \mathrm{H}), 8.23-$ $8.35 \mathrm{ppm}(m, 4 \mathrm{H}) .{ }^{13} \mathrm{C}$ NMR (50 MHz, DMSO): $\delta=129.5,131.3$, $143.0 \mathrm{ppm}$. IR (KBr, $\left.\nu, \mathrm{cm}^{-1}\right)$ : 3678(br), 3059(w), 3009(w), 1516(m), 1472(w), 1419(s), 1384(vs.), 1361(s), 1297(vs.), 1209(m), 1167(w), 1152(m), 1119(m), 1063(w), 1029(m), 1002(w), 977(w), 953(w), 906(w), 863(w), 828(m), 791(w), 745(s), 660(w), 596(m), $552(\mathrm{w}), 528(\mathrm{w}), 502(\mathrm{w}), 480(\mathrm{w}), 459(\mathrm{w})$. UV-vis (DMSO, $\left.\lambda_{\max }, \mathrm{nm}\right):$ $366.0\left(\varepsilon=7.7 \times 10^{3} \mathrm{M}^{-1} \mathrm{~cm}^{-1}\right)$.

\section{Measurements}

Elemental analyses for carbon, hydrogen and nitrogen of the synthesized gold(III) and silver(I) complexes were performed by the Microanalytical Laboratory, Faculty of Chemistry, University of Belgrade. NMR spectra of gold(III) complexes Au1-5 were recorded at $25^{\circ} \mathrm{C}$ in $\mathrm{CD}_{3} \mathrm{COCD}_{3}$ on a Bruker Avance III $400 \mathrm{MHz}$ spectrometer $\left({ }^{1} \mathrm{H}\right.$ at $400 \mathrm{MHz},{ }^{13} \mathrm{C}$ at $\left.101 \mathrm{MHz}\right)$, equipped with a $5 \mathrm{~mm}$ dual ${ }^{13} \mathrm{C} /{ }^{1} \mathrm{H}$ probe head, while those of silver(I) complexes Ag1-5 were recorded in DMSO- $d_{6}$ on a Varian Gemini 2000 spectrometer $\left({ }^{1} \mathrm{H}\right.$ at $200 \mathrm{MHz},{ }^{13} \mathrm{C}$ at $\left.50 \mathrm{MHz}\right)$. Chemical shifts are reported in parts per million (ppm) and scalar couplings are reported in hertz. $10 \mathrm{mg}$ of each complex was dissolved in $0.7 \mathrm{~mL}$ of the corresponding solvent, and this solution was transferred into a $5 \mathrm{~mm}$ NMR tube. It is important to note that Au1-5 are unstable in DMSO solvent and readily undergo decomposition to yield free diazaaromatic compounds. ${ }^{24,25}$ This problem often occurs for $\mathrm{Au}(\mathrm{III})$ chlorideazine complexes and should be always taken into account when working with this solvent. ${ }^{71,72}$ Infrared spectra were recorded as $\mathrm{KBr}$ pellets on a Perkin Elmer Spectrum One spectrometer over the range of 450-4000 $\mathrm{cm}^{-1}$. The UV-vis spectra were recorded on a Cary 100 spectrophotometer (Varian, USA), after dissolving the corresponding gold(III) and silver(I) complex in $\mathrm{DMF} / \mathrm{H}_{2} \mathrm{O}$ $(1: 1, \mathrm{v} / \mathrm{v})$ mixture and DMSO, respectively, as well as after $24 \mathrm{~h}$ of incubation in the dark at $37{ }^{\circ} \mathrm{C}$, over the wavelength range of 200-600 nm. The concentration of the gold(III) and silver(I) complexes was 0.50 and $0.25 \mathrm{mg} \mathrm{mL}^{-1}$, respectively.

\section{Air/light stability of gold(III) and silver(I) complexes}

The air/light stability of the gold(III) complexes Au1-5 and the corresponding silver(I) complexes Ag1-5 was studied by indirect light in air atmosphere at room temperature. Sterile cellulose discs were impregnated with the gold(III) and silver(I) complexes (200 $\mu \mathrm{g}$ per disc, using $50 \mathrm{mg} \mathrm{mL}^{-1}$ DMF and DMSO stock solution, respectively) and exposed to air and light. The stability was monitored visually within $96 \mathrm{~h}$.

\section{Antimicrobial and cytotoxicity studies}

Minimal inhibitory concentrations (MIC) of $\mathrm{Au}(\mathrm{III})$ and $\mathrm{Ag}(\mathrm{I})$ complexes 1-5, and the starting $\mathrm{AgNO}_{3}$ and $\mathrm{K}\left[\mathrm{AuCl}_{4}\right]$ 
compounds, were determined according to the standard broth microdilution assays, recommended by the National Committee for Clinical Laboratory Standards (M07-A8) for bacteria and Standards of European Committee on Antimicrobial Susceptibility Testing (EDef7.1.). The tested Au(III) complexes were dissolved in DMF, while $\mathrm{Ag}$ (I) complexes were dissolved in DMSO. The highest concentration used was $250 \mu \mathrm{g}$ $\mathrm{mL}^{-1}$. The inoculums were $10^{5}$ colony-forming units (cfu $\mathrm{mL}^{-1}$ )

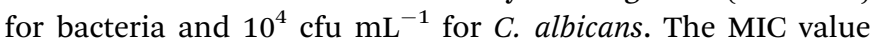
corresponds to the lowest concentration that inhibited the growth after $24 \mathrm{~h}$ at $37{ }^{\circ} \mathrm{C}$. The $\mathrm{AgNO}_{3}$ salt was considered as positive control, as it has been used clinically. ${ }^{73}$ To assess the activity of the compounds in different bacteriological media, Luria Broth (LB) as well as RPMI-1640 medium supplemented with LB $(5 \%, \mathrm{v} / \mathrm{v})$ were utilized. ${ }^{45}$

Cell viability was tested by the 3-(4,5-dimethylthiazol-2-yl)2,5-diphenyltetrazolium bromide (MTT) assay. ${ }^{74}$ The assay was carried out using human lung fibroblasts (MRC5) after $48 \mathrm{~h}$ of cell incubation in the medium, containing compounds at concentrations ranging from 0.1 to $100 \mu \mathrm{g} \mathrm{mL}^{-1}$. The MRC5 cell line was maintained in RPMI-1640 medium supplemented with $100 \mu \mathrm{g} \mathrm{mL}^{-1}$ streptomycin, $100 \mathrm{U} \mathrm{mL}^{-1}$ penicillin and $10 \%(\mathrm{v} / \mathrm{v})$ fetal bovine serum (FBS) (all from Sigma, Munich, Germany) as a monolayer $\left(1 \times 10^{4}\right.$ cells per well) and grown in humidified atmosphere of $95 \%$ air and $5 \% \mathrm{CO}_{2}$ at $37^{\circ} \mathrm{C}$. The extent of MTT reduction was measured spectrophotometrically at $540 \mathrm{~nm}$ using a Tecan Infinite 200 Pro multiplate reader (Tecan Group Ltd., Männedorf, Switzerland), and the cell survival was expressed as percentage of the control (untreated cells). The percentage viability values were plotted against the log of concentration and a sigmoidal dose response curve was calculated by non-linear regression analysis, using the Graphpad Prism software, version 5.0 for Windows (Graphpad Software, CA, USA). Cytotoxicity is expressed as the concentration of the compound inhibiting growth by $50 \%\left(\mathrm{IC}_{50}\right)$.

Disruption of $\boldsymbol{P}$. aeruginosa biofilms. Biofilm quantification assays were performed in microtiter plate format using a crystal violet staining of adherent cells. ${ }^{75}$ Biofilm disruption assay was performed in 24-well microtiter plate as previously described. ${ }^{76}$ $P$. aeruginosa cultures were grown overnight in M9 medium at $37{ }^{\circ} \mathrm{C}$ with shaking at $180 \mathrm{rpm}$ and subcultured in 24-well microtiter plate $(1 \% \mathrm{v} / \mathrm{v}$ inoculums in $1.0 \mathrm{~mL}$ M9 medium supplemented with $20 \mathrm{mM}$ glucose) and further incubated at 37 ${ }^{\circ} \mathrm{C}$ with $180 \mathrm{rpm}$ shaking. Test compounds were added at concentration of determined MIC value after $6 \mathrm{~h}$ of growth. After $1 \mathrm{~h}$ planktonic cells were removed, wells washed with PBS and adherent cells were stained with crystal violet.

Live/dead staining of the bacterial biofilms. To study the effect of gold(III) and silver(I) complexes on P. aeruginosa PAO1 biofilms, overnight bacterial culture grown in LB medium was diluted to optical density OD600 of 0.05 in M9 medium and the biofilms were grown on glass cover slips in the presence of selected metal complexes or their mixtures or solvent vehicle. After $24 \mathrm{~h}$ growth at $37^{\circ} \mathrm{C}$, biofilms were washed with $0.9 \%(\mathrm{w} / \mathrm{v})$ $\mathrm{NaCl}$ and stained with $2.5 \mu \mathrm{M}$ SYTO9 green fluorescent dye and $2.5 \mu \mathrm{M}$ propidium iodide (PI) red fluorescent dye of Live/Dead staining kit (LIVE/DEAD ${ }^{\circledR}$ BacLight ${ }^{\mathrm{TM}}$ Bacterial Viability Kit,
Thermo Fisher Scientific, Waltham, MA, USA). Biofilms and cells were observed under a fluorescence microscope (Olympus BX51, Applied Imaging Corp., San Jose, USA) at $1000 \times$ magnification.

Synergy testing. Complexes Au1 and Au3, as well as Ag1 were selected for synergy testing after reviewing individual MIC and $\mathrm{IC}_{50}$ concentrations using previously described checkerboard microdilution method. ${ }^{77}$ Briefly, the broth microdilution plates were inoculated with $P$. aeruginosa PAO1 to yield the appropriate density $\left(10^{5} \mathrm{cfu} \mathrm{mL} \mathrm{m}^{-1}\right)$ in $100 \mu \mathrm{L} \mathrm{LB}$ broth and incubated for 24 $\mathrm{h}$ at $37^{\circ} \mathrm{C}$. One well with no antibiotic was used as a positive growth control on each plate. Plates were read for visual turbidity and spectrophotometrically at $600 \mathrm{~nm}$, and results were recorded after $24 \mathrm{~h}$ of incubation at $37^{\circ} \mathrm{C}$ as turbidity in wells indicated growth of the microorganism. The MIC was determined in the microtiter plate with the lowest drug concentration at which there was no visible growth. The MICs of single drugs $\mathrm{A}$ and $\mathrm{B}\left(\mathrm{MIC}_{\mathrm{A}}\right.$ and $\left.\mathrm{MIC}_{\mathrm{B}}\right)$ and in combination $\left(\mathrm{MIC}_{\mathrm{AB}}\right)$ were determined after $24 \mathrm{~h}$ of incubation at $37{ }^{\circ} \mathrm{C}$. $\mathrm{MIC}_{\mathrm{AB}}$ was defined as the MIC of drug $\mathrm{A}$ in the presence of drug B.

The fractional inhibitory concentration index (FICI) was calculated for each complex in each combination by using the following formula: $\mathrm{FIC}_{\mathrm{A}}+\mathrm{FIC}_{\mathrm{B}}=\mathrm{FICI}$, where $\mathrm{FIC}_{\mathrm{A}}$ equals the MIC of drug $A$ in combination divided by the MIC of drug A alone and $\mathrm{FIC}_{\mathrm{B}}$ equals the MIC of drug $\mathrm{B}$ in combination divided by the MIC of drug B alone. The FICIs were interpreted as follows: synergy, FICI of $\leq 0.5$; $\leq 1$; additivity or no interaction, FICI of $>1$ to $\leq 2$; antagonism, FICI of $>4$.

\section{In vitro DNA interaction by gel electrophoresis assay}

Genomic DNA (gDNA) from $P$. aeruginosa PAO1 was purified with a DNeasy tissue kit (Qiagen, Hilden, Germany). The quality and the concentration of DNA were estimated by measuring UV absorbance with a NanoVue Plus spectrophotometer (GE Healthcare, Freiburg, Germany). The ability of Au1-5 and Ag1-5 to bind gDNA from $P$. aeruginosa PAO1 was examined by using agarose gel electrophoresis. ${ }^{\mathbf{5 0}, 78}$ For the gel electrophoresis experiments, gDNA (500 ng) was treated with the investigated compounds $\left(25 \mu \mathrm{g} \mathrm{mL}{ }^{-1}\right)$ in phosphate buffer ( $\left.\mathrm{pH} 7.4\right)$, and the contents were incubated for $12 \mathrm{~h}$ at $37{ }^{\circ} \mathrm{C}$, then subjected to gel electrophoresis on $0.8 \%(\mathrm{w} / \mathrm{v})$ agarose gel containing $0.1 \mu \mathrm{g}$ $\mathrm{mL}^{-1}$ of ethidium bromide in TAE buffer ( $40 \mathrm{mM}$ Tris acetate/1 mM EDTA, pH 7.4) buffer at $60 \mathrm{~V}$ for $2 \mathrm{~h}$. Gels were visualized and analyzed using the Gel Doc EZ system (Bio-Rad, Life Sciences, Hercules, USA), equipped with the Image Lab ${ }^{\mathrm{TM}}$ Software.

\section{Molecular docking}

The geometry optimization of gold(III) and silver(I) complexes has been carried out with the application of semi-empirical quantum chemistry method (PM6), ${ }^{79,80}$ because of its excellent compromise between computational time and description of electronic correlation. ${ }^{58}$ Semi-empirical level of theory was successfully applied to metal complexes geometry optimization in similar docking studies. ${ }^{\mathbf{8 1 , 8 2}}$ The calculations were performed 
with the Gaussian 09 software package. ${ }^{83}$ As a model to study the interaction between the silver(I) and gold(III) complexes and DNA, the structure of B-DNA dodecamer (CGCGAATTCGCG) (PDB:1BNA) was used. ${ }^{\mathbf{8 4}, 85}$ The investigated complexes were docked into the rigid DNA structure using the Molegro Virtual Docker (MVD v. 2013.6.0.1.). ${ }^{86}$ MVD has been successfully applied in the docking studies of silver(I) and gold(III) complexes in DNA. ${ }^{87,88}$ Hydrogen bonds, hydrophilic and hydrophobic interactions between gold(III) and silver(I) complexes and DNA were calculated. The binding site was computed with a grid resolution of $0.3 \AA$. The MolDock SE as a search algorithm was used with the number of runs set to 100 . The parameters of docking procedure were: population size 50, maximum number of iterations 1500, energy threshold 100.00 and maximum number of steps 300 . The number of generated poses was 5 . The estimation of gold(III) and silver(I) complexes and DNA interactions was described by the MVD-related scoring functions: MolDock score, docking score, Rerank score, Hbond score, van der Waals (vdW) score, steric interactions, vdW, Hbond and NonHBond interaction with DNA and ligand efficiency (LE). A maximum population of 100 and maximum iterations of 10000 were used for each run and the 5 best poses were retained. Visualization of the docked pose has been done by using CHIMERA (http://www.cgl.ucsf.edu/chimera/) molecular graphics program.

\section{In vivo zebrafish toxicity assay}

Adult zebrafish (Danio rerio, wild type) were maintained in the fish medium ( $2 \mathrm{mM} \mathrm{CaCl}_{2}, 0.5 \mathrm{mM} \mathrm{MgSO} 4,0.7 \mathrm{mM} \mathrm{NaHCO}$, $0.07 \mathrm{mM} \mathrm{KCl}$ ) at $27 \pm 1{ }^{\circ} \mathrm{C}$ and $14 \mathrm{~h}$ light/10 h dark cycle, and regularly fed twice daily with commercially dry flake food supplemented with Artemia nauplii (TetraMin ${ }^{\mathrm{TM}}$ flakes; Tetra Melle, Germany). Embryos were treated at 4 hours post fertilization (hpf) with four different concentrations $(5,10,25$ and $50 \mu \mathrm{g}$ $\mathrm{mL}^{-1}$ ), and 0.1\% DMF and DMSO were used as negative control. Embryos were then transferred into 24-well plates containing $1000 \mu \mathrm{L}$ test solution, 8 embryos per well (24 embryos per concentration), and incubated at $28{ }^{\circ} \mathrm{C}$.

Apical endpoints (Table S3†) used for toxicity evaluation were recorded at 24, 48, 72, 96 and 114 hpf using an inverted microscope (CKX41; Olympus, Tokyo, Japan). At $114 \mathrm{hpf}$, the embryos were anesthetized by addition of $0.1 \%(\mathrm{w} / \mathrm{v})$ tricaine solution (Sigma-Aldrich, St. Louis, MO), photographed and killed by freezing at $-20{ }^{\circ} \mathrm{C}$ for $\geq 24 \mathrm{~h}$.

All experiments involving zebrafish were performed in compliance with the European directive 86/609/EEC and the ethical guidelines of the Guide for Care and Use of Laboratory Animals of the Institute for Molecular Genetics and Genetic Engineering, University of Belgrade.

\section{Conclusions}

In this study, five gold(III) complexes Au1-5 and five silver(I) complexes Ag1-5 with the aromatic nitrogen-containing heterocycles, pyridazine (pydz), pyrimidine (pm), pyrazine (pz), quinoxaline (qx) and phenazine (phz), have been synthesized and structurally characterized by using different spectroscopic techniques. All investigated gold(III) complexes are mononuclear and have square-planar geometry, while the corresponding silver(I) complexes are polynuclear and adopt different geometries. The investigation of the air/light stability of the solutions of Au1-5 and Ag1-5 complexes show that the gold(III) complexes are substantially more stable than the silver(I) analogues. The obtained results of biological evaluation reveal that Ag1-5 complexes manifested better activity against different bacterial strains and the fungus $C$. albicans than that of Au1-5 complexes. On the other hand, Au1-5 complexes exhibited much lower negative effects on the viability of the normal human lung fibroblast cell line MRC5 in comparison to Ag1-5 complexes, which is a desirable property for application of these compounds as antimicrobial agents. For both of the metal complexes, it can be concluded that the antimicrobial and cytotoxic activity depends on the number of aromatic rings in the N-heterocyclic ligands. Moreover, using combination approach, we confirmed the synergies of silver(I) and gold(III) complexes, i.e. the obtained data clearly demonstrated that Au1/ Ag1 8 : 1 and Au3/Ag1 6.4: 1 mixtures had higher antimicrobial, $P$. aeruginosa PAO1 biofilm-disruption activity and improved safety toward human fibroblast and zebrafish embryos than the tested single complexes. This synergistic effect of gold(III) and silver(I) complexes with the aromatic N-heterocycles can be further exploited for the design of novel therapeutic agents with the improved biological/pharmacological profiles.

\section{Acknowledgements}

This work has been financially supported by the Ministry of Education, Science and Technological Development, Republic of Serbia, under Grants No. 172036 and 173048. J. B. Veselinović greatly acknowledges Dr Željko Vitnik (Department of Chemistry, IChTM - Institute of Chemistry, Technology and Metallurgy, University of Belgrade, Belgrade, Serbia) for providing the G09 and computing facilities.

\section{Notes and references}

1 D. Gaynor and D. M. Griffith, Dalton Trans., 2012, 41, 1323913257.

2 C. F. Shaw, in Encyclopedia of Inorganic and Bioinorganic Chemistry, John Wiley \& Sons, Ltd, 2011.

3 S. Medici, M. Peana, V. M. Nurchi, J. I. Lachowicz, G. Crisponi and M. A. Zoroddu, Coord. Chem. Rev., 2015, 284, 329-350.

4 K. D. Mjos and C. Orvig, Chem. Rev., 2014, 114, 4540-4563.

5 F. Bertolini, V. P. Sukhatme and G. Bouche, Nat. Rev. Clin. Oncol., 2015, 12, 732-742.

6 B. Đ. Glišić and M. I. Djuran, Dalton Trans., 2014, 43, 59505969.

7 A. R. Sannella, A. Casini, C. Gabbiani, L. Messori, A. R. Bilia, F. F. Vincieri, G. Majori and C. Severini, FEBS Lett., 2008, 582, 844-847. 
8 E. I. Gkaniatsou, C. N. Banti, N. Kourkoumelis, S. Skoulika, M. Manoli, A. J. Tasiopoulos and S. K. Hadjikakou, J. Inorg. Biochem., 2015, 150, 108-119.

9 V. Joszai, I. Turi, C. Kallay, G. Pappalardo, G. Di Natale, E. Rizzarelli and I. Sovago, J. Inorg. Biochem., 2012, 112, 1724.

10 A. C. Ekennia, D. C. Onwudiwe, C. Ume and E. E. Ebenso, Bioinorg. Chem. Appl., 2015, 2015, 913424.

11 M. Kriechbaum and U. Monkowius, Annu. Rep. Prog. Chem., Sect. A: Inorg. Chem., 2013, 109, 188-199.

12 I. Ott, Coord. Chem. Rev., 2009, 253, 1670-1681.

13 A. B. G. Lansdown, Silver in healthcare. Its antimicrobial efficacy and safety in use, Royal Society of Chemistry, Cambridge, 2010, vol. 6 .

14 K. Mijnendonckx, N. Leys, J. Mahillon, S. Silver and R. Van Houdt, BioMetals, 2013, 26, 609-621.

15 R. Rowan, T. Tallon, A. M. Sheahan, R. Curran, M. McCann, K. Kavanagh, M. Devereux and V. McKee, Polyhedron, 2006, 25, 1771-1778.

16 C. P. Randall, A. Gupta, N. Jackson, D. Busse and A. J. O'Neill, J. Antimicrob. Chemother., 2015, 70, 1037-1046.

17 S. J. Berners-Price, in Bioinorganic Medicinal Chemistry, ed. E. Alessio, Wiley-VCH, Wienheim, 2011, pp. 197-222.

18 B. Đ. Glišić, L. Senerovic, P. Comba, H. Wadepohl, A. Veselinovic, D. R. Milivojevic, M. I. Djuran and J. Nikodinovic-Runic, J. Inorg. Biochem., 2016, 155, 115-128.

19 L. Ortego, J. Gonzalo-Asensio, A. Laguna, M. D. Villacampa and M. C. Gimeno, J. Inorg. Biochem., 2015, 146, 19-27.

20 M. Sullivan, A. F.-A. Kia, M. Long, M. Walsh, K. Kavanagh, S. McClean and B. S. Creaven, Polyhedron, 2014, 67, 549-559.

21 C. Kaes, A. Katz and M. W. Hosseini, Chem. Rev., 2000, 100, 3553-3590.

22 P. J. Steel, Coord. Chem. Rev., 1990, 106, 227-265.

23 C. J. Sumby, Coord. Chem. Rev., 2011, 255, 1937-1967.

24 B. Đ. Glišić, B. Warżajtis, N. S. Radulović, U. Rychlewska and M. I. Djuran, Polyhedron, 2015, 87, 208-214.

25 B. Warżajtis, B. Đ. Glišić, N. S. Radulović, U. Rychlewska and M. I. Djuran, Polyhedron, 2014, 79, 221-228.

26 M. A. M. Abu-Youssef, V. Langer and L. Öhrström, Dalton Trans., 2006, 2542-2550.

27 L. Carlucci, G. Ciani, D. M. Proserpio and A. Sironi, Inorg. Chem., 1998, 37, 5941-5943.

28 M. Munakata, S. Kitagawa, N. Ujimaru, M. Nakamura, M. Maekawa and H. Matsuda, Inorg. Chem., 1993, 32, 826-832.

29 C. V. K. Sharma and R. D. Rogers, Cryst. Eng., 1998, 1, 19-38.

30 R. G. Vranka and E. L. Amma, Inorg. Chem., 1966, 5, 10201025.

31 B. Đ. Glišić, Z. D. Stanić, S. Rajković, V. Kojić, G. Bogdanović and M. I. Djuran, J. Serb. Chem. Soc., 2013, 78, 1911-1924.

32 M. Rizzotto, in A Search for Antibacterial Agents, ed. V. Bobbarala, InTech, Rijeka, Croatia, 2012, pp. 73-88.

33 S. S. Al-Jaroudi, M. Altaf, A. A. Al-Saadi, A.-N. Kawde, S. Altuwaijri, S. Ahmad and A. A. Isab, BioMetals, 2015, 28, 827-844.

34 U. Kalinowska-Lis, A. Felczak, L. Chęcińska, K. Zawadzka, E. Patyna, K. Lisowska and J. Ochocki, Dalton Trans., 2015, 44, 8178-8189.
35 F. Perez, J. Adachi and R. A. Bonomo, Clin. Infect. Dis., 2014, 59, S335-S339.

36 G. Samonis, K. Z. Vardakas, D. P. Kofteridis, D. Dimopoulou, A. M. Andrianaki, I. Chatzinikolaou, E. Katsanevaki, S. Maraki and M. E. Falagas, Infection, 2014, 42, 721-728.

37 R. V. Parish, B. P. Howe, J. P. Wright, J. Mack, R. G. Pritchard, R. G. Buckley, A. M. Elsome and S. P. Fricker, Inorg. Chem., 1996, 35, 1659-1666.

38 I. Ozdemir, N. Temelli, S. Gunal and S. Demir, Molecules, 2010, 15, 2203-2210.

39 C. de Martel, J. Ferlay, S. Franceschi, J. Vignat, F. Bray, D. Forman and M. Plummer, Lancet Oncol., 2012, 13, 607-615.

40 E. Elinav, R. Nowarski, C. A. Thaiss, B. Hu, C. Jin and R. A. Flavell, Nat. Rev. Cancer, 2013, 13, 759-771.

41 R. F. Schwabe and C. Jobin, Nat. Rev. Cancer, 2013, 13, 800-812. 42 N. Savić, B. Đ. Glišić, H. Wadepohl, A. Pavic, L. Senerovic, J. Nikodinovic-Runic and M. Djuran, MedChemComm, 2015, DOI: 10.1039/c5md00494b.

43 L. R. Gouvea, L. S. Garcia, D. R. Lachter, P. R. Nunes, F. de Castro Pereira, E. P. Silveira-Lacerda, S. R. W. Louro, P. J. S. Barbeira and L. R. Teixeira, Eur. J. Med. Chem., 2012, 55, 67-73.

44 N. Pantelić, T. P. Stanojković, B. B. Zmejkovski, T. J. Sabo and G. N. Kaluđerović, Eur. J. Med. Chem., 2015, 90, 766-774.

45 L. Lin, P. Nonejuie, J. Munguia, A. Hollands, J. Olson, Q. Dam, M. Kumaraswamy, H. Rivera Jr, R. Corriden, M. Rohde, M. E. Hensler, M. D. Burkart, J. Pogliano, G. Sakoulas and V. Nizet, EBioMedicine, 2015, 2, 690-698.

46 T. Bjarnsholt, K. Kirketerp-Moller, S. Kristiansen, R. Phipps, A. K. Nielsen, P. O. Jensen, N. Hoiby and M. Givskov, APMIS, 2007, 115, 921-928.

47 V. Kostenko, J. Lyczak, K. Turner and R. J. Martinuzzi, Antimicrob. Agents Chemother., 2010, 54, 5120-5131.

48 A. Casini, M. A. Cinellu, G. Minghetti, C. Gabbiani, M. Coronnello, E. Mini and L. Messori, J. Med. Chem., 2006, 49, 5524-5531.

49 S. Mandal, A. Hepp and J. Muller, Dalton Trans., 2015, 44, 3540-3543.

50 V. T. Yilmaz, E. Gocmen, C. Icsel, M. Cengiz, S. Y. Susluer and O. Buyukgungor, J. Photochem. Photobiol., B, 2014, 131, 31-42.

51 Q. L. Feng, J. Wu, G. Q. Chen, F. Z. Cui, T. N. Kim and J. O. Kim, J. Biomed. Mater. Res., 2000, 52, 662-668.

52 B. Bertrand and A. Casini, Dalton Trans., 2014, 43, 42094219.

53 A. Casini, C. Hartinger, C. Gabbiani, E. Mini, P. J. Dyson, B. K. Keppler and L. Messori, J. Inorg. Biochem., 2008, 102, 564-575.

54 P. Shi, Q. Jiang, Y. Zhao, Y. Zhang, J. Lin, L. Lin, J. Ding and Z. Guo, J. Biol. Inorg. Chem., 2006, 11, 745-752.

55 S. Carotti, G. Marcon, M. Marussich, T. Mazzei, L. Messori, E. Mini and P. Orioli, Chem.-Biol. Interact., 2000, 125, 29-38.

56 N. Raman, S. Sobha and L. Mitu, Monatsh. Chem., 2012, 143, 1019-1030.

57 Q. Saquib, A. A. Al-Khedhairy, S. A. Alarifi, S. Dutta, S. Dasgupta and J. Musarrat, Int. J. Biol. Macromol., 2010, 47, 68-75. 
58 R. Filosa, A. Peduto, S. Di Micco, P. de Caprariis, M. Festa, A. Petrella, G. Capranico and G. Bifulco, Bioorg. Med. Chem., 2009, 17, 13-24.

59 A. G. Freifeld, E. J. Bow, K. A. Sepkowitz, M. J. Boeckh, J. I. Ito, C. A. Mullen, I. I. Raad, K. V. Rolston, J.-A. H. Young and J. R. Wingard, Clin. Infect. Dis., 2011, 52, e56-e93.

60 Z. R. Smith, S. K. Tajchman, B. M. Dee, J. J. Bruno, W. Qiao and F. P. Tverdek, J. Oncol. Pharm. Pract., 2015, DOI: 10.1177/ 1078155215586081.

61 R. Ben-Knaz, R. Pedahzur and D. Avnir, RSC Adv., 2013, 3, 8009-8015.

62 M. B. Habash, A. J. Park, E. C. Vis, R. J. Harris and C. M. Khursigara, Antimicrob. Agents Chemother., 2014, 58, 5818-5830.

63 M. D. Rhodes, P. J. Sadler, M. D. Scawen and S. Silver, J. Inorg. Biochem., 1992, 46, 129-142.

64 C. Chakraborty, C. H. Hsu, Z. H. Wen, C. S. Lin and G. Agoramoorthy, Curr. Drug Metab., 2009, 10, 116-124.

65 C. A. MacRae and R. T. Peterson, Nat. Rev. Drug Discovery, 2015, 14, 721-731.

66 Z. Gong and V. Korzh, Fish Development and Genetics: The Zebrafish and Medaka Models, World Scientific Publishing Co., Singapore, 2004.

67 S. Bourrachot, O. Simon and R. Gilbin, Aquat. Toxicol., 2008, 90, 29-36.

68 S. Lin, Y. Zhao, Z. Ji, J. Ear, C. H. Chang, H. Zhang, C. LowKam, K. Yamada, H. Meng, X. Wang, R. Liu, S. Pokhrel, L. Madler, R. Damoiseaux, T. Xia, H. A. Godwin, S. Lin and A. E. Nel, Small, 2013, 9, 1776-1785.

69 O. Bar-Ilan, R. M. Albrecht, V. E. Fako and D. Y. Furgeson, Small, 2009, 5, 1897-1910.

70 I. Ott, X. Qian, Y. Xu, D. H. Vlecken, I. J. Marques, D. Kubutat, J. Will, W. S. Sheldrick, P. Jesse, A. Prokop and C. P. Bagowski, J. Med. Chem., 2009, 52, 763-770.

71 Y. Fuchita, H. Ieda, A. Kayama, J. Kinoshita-Nagaoka, H. Kawano, S. Kameda and M. Mikuriya, Dalton Trans., 1998, 4095-4100.
72 D. Niedzielska, T. Pawlak, M. Bozejewicz, A. Wojtczak, L. Pazderski and E. Szłyk, J. Mol. Struct., 2013, 1032, 195-202. 73 H. J. Klasen, Burns, 2000, 26, 131-138.

74 M. B. Hansen, S. E. Nielsen and K. Berg, J. Immunol. Methods, 1989, 119, 203-210.

75 J. H. Merritt, D. E. Kadouri and G. A. O'Toole, Current protocols in microbiology, unit 1B.1, 2005, ch. 1.

76 N. Barraud, J. A. Moscoso, J. M. Ghigo and A. Filloux, Methods Mol. Biol., 2014, 1149, 643-651.

77 M. M. Sopirala, J. E. Mangino, W. A. Gebreyes, B. Biller, T. Bannerman, J.-M. Balada-Llasat and P. Pancholi, Antimicrob. Agents Chemother., 2010, 54, 4678-4683.

78 P. Smolenski, S. W. Jaros, C. Pettinari, G. Lupidi, L. Quassinti, M. Bramucci, L. A. Vitali, D. Petrelli, A. Kochel and A. M. Kirillov, Dalton Trans., 2013, 42, 65726581.

79 E. A. Amin and D. G. Truhlar, J. Chem. Theory Comput., 2008, 4, 75-85.

80 J. J. P. Stewart, J. Mol. Model., 2007, 13, 1173-1213.

81 A. M. A. Alaghaz, B. A. El-Sayed, A. A. El-Henawy and R. A. A. Ammar, J. Mol. Struct., 2013, 1035, 83-93.

82 R. Cincinelli, L. Musso, S. Dallavalle, R. Artali, S. Tinelli, D. Colangelo, F. Zunino, M. De Cesare, G. L. Beretta and N. Zaffaroni, Eur. J. Med. Chem., 2013, 63, 387-400.

83 M. J. Frisch, et al., Gaussian 09, Revision C.02, Wallingford, CT, 2004.

84 H. R. Drew, R. M. Wing, T. Takano, C. Broka, S. Tanaka, K. Itakura and R. E. Dickerson, Proc. Natl. Acad. Sci. U. S. A., 1981, 78, 2179-2183.

85 K. Suntharalingam, O. Mendoza, A. A. Duarte, D. J. Mann and R. Vilar, Metallomics, 2013, 5, 514-523.

86 R. Thomsen and M. H. Christensen, J. Med. Chem., 2006, 49, 3315-3321.

87 A. A. Adeniyi and P. A. Ajibade, Molecules, 2013, 18, 1082910856.

88 L. Senerovic, M. D. Zivkovic, A. Veselinovic, A. Pavic, M. I. Djuran, S. Rajkovic and J. Nikodinovic-Runic, J. Med. Chem., 2015, 58, 1442-1451. 